Portland State University

PDXScholar

1977

\title{
Social work intervention and patients' utilization of the Kaiser health care system
}

\author{
Pegi Sten \\ Portland State University \\ Liz Swint Young \\ Portland State University
}

Follow this and additional works at: https://pdxscholar.library.pdx.edu/open_access_etds

Part of the Medicine and Health Commons, and the Social Work Commons Let us know how access to this document benefits you.

\section{Recommended Citation}

Sten, Pegi and Young, Liz Swint, "Social work intervention and patients' utilization of the Kaiser health care system" (1977). Dissertations and Theses. Paper 1903.

https://doi.org/10.15760/etd.1902

This Thesis is brought to you for free and open access. It has been accepted for inclusion in Dissertations and Theses by an authorized administrator of PDXScholar. Please contact us if we can make this document more accessible: pdxscholar@pdx.edu. 
SOCIAL WORK INTERVENTION AND

PATIENTS' UTILIZATION OF THE

KAISER HEALTH CARE SYSTEM

by

PEGI STEN

LIZ SWINT YOUNG

A practicum submitted in partial fulfillment of the requirements for the degree of

MASTER OF SOCIAL WORK

Portland State University

1977 
TO THE OFFICE OF GRADUATE STUDIES AND RESEARCH:

The members of the Committee approve the practicum of

Pegi Sten and Liz Swint Young presented June 1, 1977.

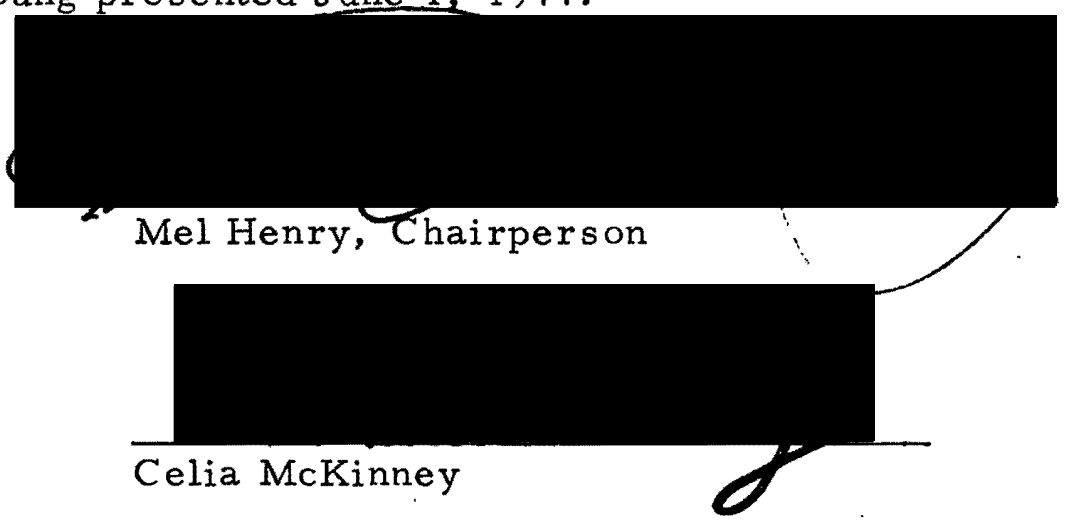


TABLE OF CONTENTS

PAGE

LIST OF TABLES ...................... v

CHAPTER

I INTRODUCTION $\ldots \ldots \ldots \ldots \ldots \ldots \ldots \ldots \ldots$

Purpose

Statement of the Problem

Significance of the Study

Setting

Role of Outpatient Social Worker

Overview of Research Proposal

II $\quad$ RELEVANT LITERATURE ............... 14

III $\quad$ METHODOLOGY .................. 32

Research Design

Sources of Data.

Research Instrument

Pilot Study

Data Collection

Limitation of Study

IV RESULTS AND FINDINGS ............. 45

Summary

V CONCLUSIONS AND RECOMMENDATIONS ..... 66

Conclusions

Recommendations 
PAGE

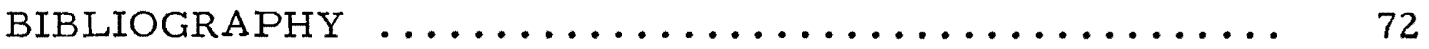

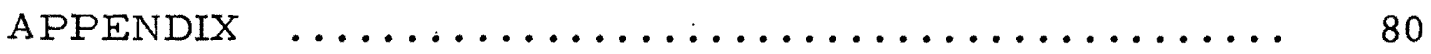




\section{LIST OF TABLES}

TABLE

PAGE

I Individual Data Sheet $\ldots \ldots \ldots \ldots \ldots \ldots \ldots \ldots \ldots$

II Category Data Sheet $\ldots \ldots \ldots \ldots \ldots \ldots \ldots \ldots \ldots$

III Age and Sex of the Sample ............. 46

IV Number of Office Visits for the Three Months

Before and After Initial Social Work

Intervention $\quad \ldots \ldots \ldots \ldots \ldots \ldots \ldots \ldots$

V Number of Physicians Seen for Three Months

Before and After Initial Social Work

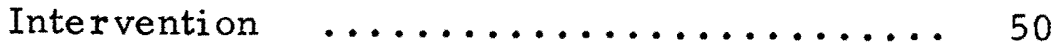

VI Number of Telephone Contacts Three Months

Before and After Initial Social Work

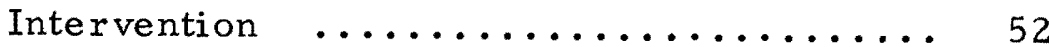

VII Number of Prescriptions for Three Months Before and After Initial Social Work Intervention .. 54

VIII Number of Emergency Room Visits for Three

Months Before and After Initial Social

Work Intervention $\ldots \ldots \ldots \ldots \ldots \ldots$ 
TABLE

PAGE

IX Hospitalizations for Three Months Before and After Initial Social Work Intervention .... 60 $\mathrm{X} \quad$ Percentage Decrease in Utilization of Services by Categories ................. 63 
CHAPTER I

\section{INTRODUCTION}

\section{$\underline{\text { Purpose }}$}

This study was an analysis of social work practice in a medical setting: analyzing the work of a medical social worker in an outpatient clinic located in a metropolitan area. The primary purpose of this descriptive study was to evaluate the performance of a medical social worker in a Kaiser-Permanente outpatient clinic and to determine if there were possible associations between social work intervention and patient utilization of existing services offered by the Kaiser Health Care system, also referred to herein as $\underline{\text { Kaiser. }}$. Specifically, the study attempted to determine if there were quantitative changes in patient contacts, and utilization of certain services such as clinic visits, telephone contacts, prescriptions, emergency room visits, hospitalizations, and physicians seen before and after social worker intervention. If there were changes, what were the direction and quantity? Did changes vary according to type of service? Did patient utilization of medical care vary according to the number of social work contacts? 
Statement of the Problem

The connection between social and environmental factors and successful treatment of physical illness has been researched and reported in a variety of fields including Medicine, Public Health, and Social Work. Brody comments,

It has been found that social stress can create or exacerbate conditions of illness and that treatment of presenting physical symptoms instead of the stressful situation may bring only temporary relief... 1

More and more the health care professions are recognizing the need to provide services to the whole person and not merely treat a symptom or disease. This has led the medical profession to recognize the need for a team approach.

One of the many functions of a medical social worker is that of coordinating the work of physicians and other allied health professionals with the needs of patients and their families. This also implies the coordination of community services and social functioning and total adjustment of patients. In addition to coordination, social workers must play a direct role in the psychosocial aspects of patient care. One writer stated it like this:

Equally important is our responsibility to influence those psychological factors that

${ }^{1}$ Stanley J. Brody. "Common Ground: Social Work and Health Care," Health and Social Work 1 (February 1976): 20 . 
predispose to illness, precipitate illness, or perpetuate illness. ${ }^{2}$

As a member of an interdisciplinary team, the social worker is an allied health professional recognized for his/her expertise in the area of psychosocial concomitants of illness.

The problem examined in this descriptive study is whether or not social work intervention appears to make a difference in the utilization of health services provided by Kaiser.

\section{Significance of the Study}

To fully understand the significance of the research problem it is necessary to explore the interrelatedness of the profession of social work and the health care system as these pertain to the needs of physically ill persons.

Social work became an integral part of the health care system when physicians and health care administrators realized that comprehensive health care meant treating the whole person and not merely the illness. Therefore, the goal of medical social work is to contribute to the total medical care provided by the health care team and directed toward achievement of the optimum state of health for the patient and his/her family.

2"The Humanization of Health Care: A Statement of Scope and Credo of Social Work in Health Care, " editorial in Social Work in Health Care 1 (Fall 1975): 5. 
The history. of medical social work is indeed associated with the history of the profession of social work. As a profession, social work actually began in a general acute hospital in Massachusetts in 1905. Since then, it has been crystalized into an organized allied health service. Today, seventy-two years later, most of the major medical centers across the country recognize the importance of social work's contribution to the treatment, restoration and rehabilitation of the individual who is ill, and also of its contribution to the prevention and education in the field of health.

It is the general concensus in contemporary society that if the treatment of physical illness is to be successful, serious consideration must be given to social factors and environmental situations which may have adverse interactive effects on the care and treatment of the patients. Thus the primary goals of medical social work are: 1) Helping the health team in understanding the significance of social, economic, emotional, psychological, and cultural factors in relation to the patient's illness, diagnosis, treatment, and subsequent recovery; 2) helping the patient and his/her family in their understanding of the factors mentioned above so that they might make constructive use of the medical care which is being provided; 3) promoting the general well-being of the patient, and improving morale during a period of crisis and illness; 4) participating in educational programs of other members of the health care 
team and helping them to understand the significance of the psychosocial aspects of health care; 5) assisting the hospital in providing better care in general by introducing humane and ethical standards concerning the needs of individuals; 6) facilitating the utilization of community resources to meet the needs of the patients and their families in a manner which will enhance and augment healthy functioning and improve the patients' recovery to health and wellbeing.

An integral part of the social worker's perception is that of seeing the patient as a whole person with an illness, and not substituting the illness for the person. The patient is not a disease, or a cadaver, or a symptom, but a person who is ill and who reacts to illness in similar manner as he/she would act to other difficulties in his/her life circumstances. In this regard, the social worker does not spend an inordinate amount of time with the particular diagnosis, but rather looks at what the disease does or is doing to the patient, how the patient feels about the disease, and what the patient's capacity may be for coping and adjusting to this disease. The social worker also looks at the support systems within the patient's environment which may enhance and/or hinder the adjustment and the course of the particular disease of the patient. Each patient then must be seen as a unique person representing a unique situation and making a unique adjustment. 
Other aspects of the social workers' values or value systems become very important in working with a health care team. For example, the social worker recognizes the importance of the concept of client participation in the decision-making process which affects him or her. Thus, the patient must be a part of the treatment plan and must accept responsibility for making important decisions in relationship to that plan. Whenever possible, alternatives must be provided with the patient's right to choose one alternative against another. Thus the social worker has the opportunity to practice another value, that of a non-judgmental attitude toward clients. The medical social worker does not pass judgment on the patient's behavior, knowing that illness with all its attending problems, real and psychological, creates conflicts and fears which may even surprise the patient him/herself. The social worker must listen with a "third" ear and demonstrate acceptance, understanding, concern, and empathy with the patient. However, they should not be insensitive to the work and role of other members of the health care team.

Inherent in the concept of a team approach to treatment is the notion that all members of the team share in the treatment process, and as such, no member of the team is greater than the other. However, because of his/her legal and pivotal functions, the physician may be regarded as the leader. Depending upon the 
particular situation, leadership roles may rotate from member to member, Since the social worker is seen as the "expert" in the area of psychosocial functioning, it may be assumed that in this area he/she will be the recognized leader. The role of the social worker parallels the definition of health care as seen by the World Health Organization:

Enjoyment of the highest attainable standards of health is one of the fundamental rights of every human being without distinction of race, religion, political belief or economic and social condition... It is the state of complete physical, mental and social well-being and not merely the absence of infirmity. 3

As implied in this definition health professions are working toward the goal of optimal health which goes beyond the treatment of disease to advances in the quality of life for the whole person.

Hinkle and Wolfe conclude that further investigation of how man's relation to his social environment affects his health should be among the foremost concerns of those in the field of medicine and public health. 4 In this study, the medical system is Kaiser, a prepaid health insurance plan, which has as a goal the unified delivery of

${ }^{3}$ Constitution of the World Health Organization, Preamble, (Geneva, Switzerland: World Health Organization, 1946), cited by Chaucey A. Alexander, "Health Care Enigmas," Health and Social Work 1 (February 1976): 11 .

${ }^{4}$ L. E. Hinkle and H. G. Wolfe, "Health and Social Environment: Experimental Investigations," in Explorations in Social Psychiatry, A.H. Leighton, et al, ed. (New York: Basic Books, 1957): 132 . 
comprehensive health care services. This study is important to the Kaiser Health Care System in its attempt to achieve the most effective utilization pattern of health care services, including preventative care. The long-term effect of effective utilization has significance in planning for future use of medical and social work resources.

It is also expected that this descriptive study will be useful to the following groups: the medical, social work and related professions as they work together toward improved coordinated health care services; policy makers in planning for future health maintenance organizations; and the general public as consumers of preventative health care.

\section{Setting}

The Kaiser system is a health maintenance organization offering comprehensive outpatient and inpatient prepaid medical care. In the Oregon region, there are approximately 200,000 subscribers, primarily from the greater Portland metropolitan area. Facilities, in this area, include two acute care hospitals, seven outpatient clinics, and a home health agency all serving a physician base of over 180 physicians. Social workers have sanction to function in Kaiser's Mental Health Clinic, the federally funded Alcohol Treatment Program, and in the two hospital based Social Work Departments that also serve the seven satellite clinics. 
The Kaiser Foundation Health Plan began in the early 1930s with a single physician, Dr. Sidney Garfield, providing services to Kaiser Industry workers and their families, on a prepaid basis. In these early days, the cost to cover a worker was paid by Edgar Kaiser and amounted to $\$ 1.50$ a month per worker while the employee had deducted $.50 \xi$ a week for a spouse and $.25 \xi$ a week for each child. After World War II, when this system of prepaid medical care and Kaiser industries expanded rapidly, the plan was opened to the public. Now many industries contract with the Kaiser Foundation Health Plan (KHP) for health insurance benefits for their employees. It is also possible for an individual or family to join. The KHP, in turn, contracts out for service from two other groups: the doctors' partnership (the Kaiser-Permanente Medical Group), and the Kaiser Foundation Hospitals. These three basic components of the Kaiser system operate through at least eighteen legally separate organizational units so it is not easy to delineate the detailed structure of the Kaiser-Permanente program.

The basic features of the Kaiser program as seen by Somers are: group practice, integrated facilities (inpatient and outpatient), prepayment, reversal of economics, voluntary enrollment, and physician responsibility. ${ }^{5}$ A closed panel of doctors, working in a

${ }^{5}$ Anne R. Somers, ed. The Kaiser Permanente Medical Care Program: A Symposium (New York: Commonwealth Fund, 1971): 19-20. 
partnership arrangement, provide care on a prepaid capitation basis. A major innovation of the Kaiser system is the "dual choice" technique whereby employees may opt, individually and usually annually, between the Kaiser closed panel plan and an indemnity plan such as Blue Cross or Blue Shield. This dual choice technique gives a free choice to consumers while protecting the doctors from potentially hostile patients.

The difference between group and individual membership in the Oregon area Kaiser plan is $87 \%$ group and $13 \%$ individual. For about $30 \%$ of Kaiser group members, the employer pays the total cost. There are myriad contracts with the various employers and differing amounts paid per month by those employees who have to contribute. The most expensive, least comprehensive coverage is for those who contract with the KHP as individuals. A family of three on individual coverage will pay approximately $\$ 63.64$ per month, $\$ 2.00$ per clinic visit and half of all X-ray, laboratory fees and hospitalization costs. There is no direct fee to any patient for social work services.

The Kaiser Foundation Health Plan operates in California, Oregon, Colorado, and Hawaii and serves over two million members. This study was conducted to analyze the social work practice of a single social worker assigned to an outpatient clinic in Portland, Oregon. 
$\underline{\text { Role of Outpatient Social Worker }}$

The origin of the social work position in the outpatient clinic was largely the result of the persistent efforts of one physician. The man, a physiatrist, had previously been employed at a Veterans Administration Hospital where he was impressed with the contribution of social workers as part of the health care team. At Kaiser, there was limited social work services in the outpatient clinic because no social worker was based in the clinic itself. As the length of time spent treating certain patients increased, this physician's concern for the services of a social worker increased. After attempts to go through accepted organizational channels failed, this physiatrist selected a patient's medical record that vividly displayed excessive use of physician time and presented it to the appropriate fiscal officer. A convincing argument was made, and in March 1976, a social worker was hired and assigned to the Orthopedics and Physiatrics departments, in the outpatient clinic.

When this position was created for a social worker, it was determined that referrals would be accepted from physicians and nurses in the Orthopedic and Physiatric departments. This worker's role also includes being part of the health care teams serving several special "clinics" such as: Arthritis, Scoliosis and Neuromuscular Clinics.

Siegele noted that "Pain is the most common reason people 
seek medical assistance... Anxiety plays a major role in intensifying pain perception. "6 Likewise, pain plays a major role in the lives of the patients referred to the social worker. One of the functions of the social worker is to work with these patients to reduce anxiety levels enabling them to cope better with their pain. Beals and Hickman report:

... data suggests there is little reason to question patient's report of pain, malingering is rare. When physical evaluation reveals that degree of pain reported is inconsistent with the objective evidence of disability, the discrepancy usually represents an unconscious psychogenic elaboration of symptoms. These symptoms do not respond to treatment by physical modalities, exercises or pain meds, but may respond to appropriate management of the psychological or environmental factors making these symptoms necessary. 7

By means of her interventions, the social worker seeks to manipulate these psychological or environmental factors through a variety of means in order to increase coping mechanisms and enhance recovery from physical illness.

Overview of Research Proposal

The purpose of this descriptive study is to analyze the

"Dorothy Siegele, "The Gate Control Theory," American Journal of Nursing 74 (March 1974): 502.

${ }^{7}$ Rodney K. Beals and Norman Hickman, "Industrial Injuries of the Back and Extremities, "The Journal of Bone and Joint Surgery 54 (December 1972): 1609. 
practice of a medical social worker in an outpatient clinic to determine if any changes in patient utilization of medical services are associated with social work intervention. Data will be collected from patient medical records in order to better understand the patient's pattern of health care usage. The time frame for this study was six months - three months prior to social work intervention and three months after the initial social work contact. Thus the initial social work intervention is the independent variable. The dependent variable is patient use of the Kaiser system, defined as rates of clinic visits, telephone calls, prescriptions, emergency room visits, hospitalizations and the number of physicians involved in each case.

The population in this study comprised all patients whose cases were closed by the social worker as of December 31, 1976. To be included, the case had to have three months post initial interview by the time it was examined for data collection.

Selected case studies will be incorporated into the section on results and findings to illustrate the complex interaction between social-emotional-psychological factors and physical illness behavior. 


\section{CHAPTER II}

\section{RELEVANT LITERATURE}

The purpose of this study is an analysis of medical social work practice in an outpatient medical clinic; it is a descriptive measurement of changes, if any, between patients' use of medical services before and after social work intervention. The literature review for this study explored the following subjects: the psychosocial components of physical illness, both as causative and resultant factors; the interprofessional team approach to health care delivery of service; the actual role or functions of a medical social worker; and the related sociological concept of sick role and its behavioral manifestations.

Articles describing medical social workers in outpatient clinics were reviewed. Research into the evaluation of social work intervention was studied along with research into the effectiveness of coordination of health care efforts.

The now generally accepted hypothesis that illness behavior is not determined only by physiological factors was confirmed in a review of literature. As White points out: 


\begin{abstract}
that the emotional component of both disease and sickness is enormous, if not all persuasive. The evidence is overwhelming that the way people feel and the way they behave in response to environmental and cultural influences has a great deal to do with the form, duration, and intensity of their symptoms and dis ability. 1
\end{abstract}

The psychological, emotional, social and ethnic components of an individual's life may have significant bearing on a person's susceptibility to illness, and on that person's ability to cope with and recover from an illness.

In the late 1950s, Hinkle and Wolfe conducted extensive investigations into the relationship between health and social environment. 2 The general inference arising from these studies was that a person's relation to his/her social environment has a major influence upon his/her health. Hinkle and Wolfe found no discernible difference between healthy and ill members of groups in terms of exposure to "causative" agents, i.e., exposure to infections or toxic agents or differences in physical life experiences, but they did find a clear-cut difference in social life histories. The most

${ }^{1}$ Kerr White, "Health Care Arrangements in U.S. :A. D. 1972," in Spypos Andrepoulous, ed. "Medical Cure and Medical Care," The Milbank Memorial Fund Quarterly, 50 (October 1972): 20.

${ }^{2}$ L. E. Hinkle and H. G. Wolfe, "Health and Social Environment: Experimental Investigations," in A.H. Leighton, et al, eds., Explorations in Social Psychiatry, (New York: Basic Books, 1957): $105-132$. 
frequently ill members had been reared in families where there was dissention and conflict between parents, hostile and rejecting attitudes, divorces, emotional deprivation and unusual restrictions and demands upon the children. They conclude that:

In the population in general, those who are attempting to adapt to such difficult life situations are those who exhibit a major proportion of the illnesses occurring in the adult population. 3

The association between the physical and social-emotional aspects of ill health is even more complex than the above mentioned association between difficult life circumstances and physical illness. A distinction must be made between what appears to be objectively difficult life circumstances and what a person subjectively views as difficult life circumstances. The research has shown that it is not the objectively measureable difficulties that necessarily predispose a person to physical problems; it is the person's subjective view of their unique life situation. Hinkle and Wolfe explain that ill health is not necessarily only related to "objectively" difficult life situations:

... Illness often occurs when an individual perceives his life situation as peculiarly threatening to him, even though this life situation may not appear to be threatening to an outside observer; and that people who maintain good health in a setting to what are objectively difficult life

${ }^{3}$ Ibid. , p. 132. 
situations do not usually perceive these situations as difficult. ${ }^{4}$

The decisive factor in the great majority of illness episodes is attitude. When the individual perceives life situations unsatisfying, threatening, overdemanding, and conflicting, he is more susceptible to illness; it is not necessarily the environment per se but the individual's perception of his life situation. 5

Thus in an attempt to adequately treat any serious physical illness of an individual, it is necessary to assess the individual's psychosocial history and the unique perception of what the illness means to the individual. Elledge states,

... without this attempt to truly understand the meaning of illness to the person who is ill, we may add to the negative experiences which he is having, and therefore, contribute to his problem in dealing with his illness situation. 6

Beals and Hickman, in their study of 180 patients with injuries to the back and extremities, believe that it is not only useful but necessary to incorporate the "whole man concept" in treatment and rehabilitation efforts:

${ }^{4}$ Ibid. , p. 131.

${ }^{5}$ Hinkle and Wolfe "The Nature of Man's Adaptation to His Total Environment and the Relation of this to Illness," AMA Archives of Internal Medicine, (March 1957): 442-460.

${ }^{6}$ Caroline Elledge, "The Meaning of Illness," Medical Social Work, 3 (April 1953): 53. 
... we do not treat disease and injuries but individuals who are suffering from the effects of such disease and injuries, and that the se individuals may often have social, economic, psychological, vocational, marital, and other problems which may cause or profoundly affect their physical status. 7

The studies cited above document the role of environmental stresses leading to physical illness but the converse also applies. Physical illness can lead to complicated environmental, psychological, emotional, and social stresses. As Bartlett points out,

Illness is a reality problem that sharply modifies social roles and social functioning, (and) has a large psychosocial component (both as cause and result). ${ }^{8}$

In order to incorporate the "whole man" concept, the interrelated psychosocial components of physical illness, into a treatment program in health care, a coordination of service is needed. A health care team, comprised of physician, nurse, social worker, physical and/or occupational therapist, dietician, may be necessary to treat the inter-related and complex aspects of physical illness. As Kane states:

Teamwork is deemed necessary to insure competent, coherent, unfragmented,

${ }^{7}$ Rodney K. Beals and Norman Hickman, "Industrial Injuries of the Back and Extremities, "The Journal of Bone and Joint Surgery, 54, (December 1972) 1593-4.

8

Harriet Barlett, Analyzing Social Work Practice by Fields, (NY : NASW 1961): 47. 
and comprehensive services to people who need help. 9

The patient must be viewed as a total person who may desire total care, not just a body needing physical attention. The social, emotional, psychological needs of the patient and her family must be considered in order to supply adequate health care.

While many physicians, nurses, and paramedics may adequately consider, attempt to, and succeed in meeting the emotional and/or psychological needs of their patients, the medical profession traditionally has been somewhat lacking in a social science orientation. As one psychoanalyst points out,

... medical training itself imbues the medical student in the very first stages with dealing with a body and not a person, with literally an inanimate object, the cadaver and not a feeling, responding live human being. 10

It should not be assumed that the purpose here is an attack on the medical profession; a need for revision of medical education does exist, but the needed revision may be that of educating the medical profession to recognize the expertise of and the usefulness of another profession as part of the health care team. As Brody aptly

${ }^{9}$ Rosalie A. Kane, "The Interprofessional Team as a Small Group, "Social Work in Health Care, 1 (Fall 1975): 19.

${ }^{10}$ Anonymou's, "Notes of a Dying Professor," Pennsylvania Gazette, (Feb. 1973): 30 . 
points out:

The medical system of treatment curtails the time a physician can spend on diagnosis and treatment, especially in primary care situations. There is little opportunity for indepth exploration of psychosocial needs in a 15-minute patient interview. The emphasis is on short-term relief rather than on long-term functioning and on medical rather than on psychosocial needs. Environmental or stress-causing factors may be overlooked or considered of secondary importance. 11

A medical social worker is trained specifically to conside $x$ the psychosocial environmental factors, human needs that are important to consider in the treatment of physical illness.

Davis concludes that improvement of the human condition could come only by "interweaving medical and social forces."12 Frey states that:

The true significance of comprehensive medical care lies in the collaborative professional effort among doctors, nurses, social workers, and others in the treatment of illness, prevention of disease, and maintenance of health. 13

Forman, writing in the journal, American Family Physician, explains

${ }^{11}$ Stanly J. Brody, "Common Ground: Social Work and Health Care," Health and Social Work, 1 (Feb. 1976): 22.

${ }^{12}$ Michael Davis, "What are we Heading for in Medical Care?" American Journal of Public Health, 61 (April 1971): 652 .

${ }^{13}$ Louise Frey, Use of Groups in the Health Care Field, (New York, NASW, 1966): 9. 
that many social problems are outside the scope of a physician's responsibility and that most physicians do not have much knowledge of what social workers do. ${ }^{14}$ But, he further explains that ... once a physician becomes acquainted with the skills of a social worker and begins to work with a capable one, he is apt to be highly gratified by the breadth of assistance made available to the patient and by the increased scope of the physician's overall function. 15

Perlman describes the role of a medical social worker as assessing, diagnosing, and treating "that to which the illness is joined. 16 By adding a medical social work approach to the medical perspective, the team is not treating the disease alone but also the interrelated problems of the person who is suffering. While other professions tend to start with their particular area of interest, social work emphasizes the importance of starting where the clients are and moving with him/her toward an individualized psychosocial assessment, diagnosis and treatment plan. The initial acceptance of the individual and concern for what a particular situation means to him/her are central in social work practice and may point to the unique contribution a social worker can make to the health care team.

${ }^{14} \mathrm{~L} . \mathrm{H}$. Forman, "The Physician and the Social Worker," American Family Physician, 13 (January 1976): 90-93.

${ }^{15}$ Ibid. , p. 93.

${ }^{16}$ Helen Perlman, "The Role Concept and Social Casework," Social Service Review 36 (March 1962): 19. 
Doremus details the social worker's functions in a health care team. 17 She states that the social worker's role is to make a diagnostic assessment of whatever psychosocial problems may have been precipitated by or have contributed to the patient's illness, then to apply professional knowledge and skill, alone or in consultation with other members of the health care team to help the patient resolve the problems identified. The social worker assesses the patient's social roles, emotional reactions, interpersonal relationships and practical resources; these are the psychosocial factors of the patient's situation that are affected by illness or disability, and must be assessed to determine what intervention is indicated. In summary, Doremus states that,

Social work's function is to assist the patient and his affected family in coping with those illness-related problems - personal, interpersonal, and practical - and attendant emotional reactions with which they need help. 18

The literature describing a social worker's role in outpatient health care has been sparse. Goldberg, in an article describing graduate social work students' placements with family physicians, explained their role as having to provide social services for patients experiencing stress (which if frequently reflected in

17 Bertha Doremus, "The Four Rs: Social Diagnosis in Health Care," Health and Social Work, 1 (November 1976): 121-138. 
physical symptoms). 19 She explained that more than one-half of the patients coming to family physicians have complaints that are emotionally based. The physician, because of time pressures and frequently lack of training in psychosocial aspects, may treat symptoms instead of the patient, not seeing the interwoven aspects of the problems. Referrals made by physicians to the graduate social work students included patients needing short-term intervention around problems of obesity, drug abuse, marital, child/ parent difficulties and depression. Changes noted in the patient after social work intervention included improved health as a result of improved self-image, role functioning, and communication; and also reduced stress and anxiety. It is not clear how the se outcome results were measured in this study. Goldberg feels that providing the patient with the opportunity to express his hopes and fears and involving the patient in doing something about the stark realities with which he is living can often make the difference between recovery from illness and regression. She is optimistic that within the next five to ten years, social workers may well become an integral part of the family physician's practice. 20

Hobson and Davis report on social work in a group medical

${ }^{19}$ Ruth L. Goldberg, "The Social Worker and the Family Physician," Social Casework, 54 (October 1973): 489-495. 20 Ibid. 
practice in a Denver outpatient clinic. ${ }^{21}$ They stress the point that social work is not just for the poor and uneducated but that any individual, perhaps quite self-directed before illness, may need help in dealing with negative feelings, interpreting what has happened and what may occur, understanding altered roles, and learning new resources. The professional social worker, trained in human behavior, alert to possible hidden factors which may also need resolving, can communicate with the patient and family, and may well furnish the physician with an understanding of the patient's attitudes, environment, and aftercare possibilities, according to Hobson and Davis. Six cases were given as illustration. They conclude that,

... the social worker, by supplying the needs of patients effectively, frees additional hours for physician-patient care. Thus by increasing the physician's productive time, she actually pays her own way without fee to the patient.

No actual statistics on physician time saved are given in the Hobson/Davis article.

In 1959, Alt explained the program of social work consultation in the Health Insurance Plan of New York. ${ }^{23}$ The objectives were to

${ }^{21}$ Caroline Hobson and W. Grayburn Davis, "Social Work in Group Medical Practice," Group Practice, 18 (June 1969):25-30.

22 Ibid., p. 30.

23 Edith Alt, "Social Work Consultation in a Prepayment Medical Care Plan," American Journal of Public Health, 49 (March 1959): 350-354. 
provide direct service such as brief counselling to subscribers, consultations on community resources, and education activities. Also, helping physicians' need in handling their own feelings about patients having trouble was mentioned as a social work function. Examples of social work referrals included behavior problems in families, arrangement of care need, (for example, obtaining a wheelchair), nursing home placements, and counselling around death and dying. Alt emphasized the importance of early identification of emotional, social, and economic problems affecting health care and concluded with the hope that their experience would help to demonstrate that all subscribers in prepayment medical care plans should have social work coverage. 24

Two articles were found describing social work assistance in outpatient pediatric practice. 25 Both emphasized the social worker's role as counselling with particular skill in group, educational and preventative endeavors. Case illustrations were given describing intervention with emotional problems of referred children and their families. Collaboration with the pediatrician and allied health

${ }^{24}$ Ibid., p. 354.

25 Janet Korpela, "Social Work Assistance in Private Pediatric Practice," Social Casework, 54 (November 1973): 537-544.

${ }^{25}$ Jules Coleman, M. L. Lebowitz, and F.P. Anderson, "Social Work in a Pediatric Primary Health Care Team in a Group Practice Program," Social Work in Health Care, 1 (Summer 1976): $489-497$. 
personnel is mentioned with emphasis on extending the effectiveness of pediatric care to include the spectrum of emotional and social problems without a fragmentation of service. Helping to free physician time was an added benefit mentioned. 26

The articles describing the role of a social worker in outpatient health care do not actually evaluate the outcome or effectiveness of the service given. Benefits and advantages are referred to but it is not clear how the social work intervention is actually evaluated. Mullen, Dumpson, and Associates, in their book, Evaluation of Social Intervention, state that research on social work effectiveness is especially difficult precisely because it is not easy to hold all but one factor constant for impact evaluation. ${ }^{27}$ Segal, in analyzing fourteen years of studies (prior to 1972) published in various social work and social science journals, points out that social work is process-oriented as opposed to outcome-oriented. He states further that he knows of no study of outcome with respect to social work therapeutic interventions with both an adequate control group design and positive results. Segal reaches the conclusion that the evidence with respect to the effectiveness of social work intervention remains equivocal; he believes trends in the data

\section{${ }^{26}$ Ibid.}

27 Edward Mullen, James R. Dumpson and Associates, Evaluation of Social Intervention, (London: Jossey-Bass, Inc., 1972): 148. 
point strongly in the negative direction. 28

In spite of the lack of definitive research showing the effectiveness of social work treatment and outcome, further research was done to ascertain how the effectiveness of a medical social worker in an outpatient clinic might be objectively measured. Many of the patients referred by the physicians to the social worker are suffering from chronic illness, pain, and complex physical problems that are compounded by social-emotional stresses. One of the social worker's goals is to reduce the anxiety and stress enabling the patient to cope better with the illness and/or pain. One study cited research showing the relationship between stress and illness in general being measured behaviorally by frequency of medical visits. 29

Further investigations into behavioral components of physical illness led to consideration of the sick role concept. Parsons originated the concept of sick role behavior referring to a sick person's exemption from responsibility for their incapacity, that the illness was beyond the person's control and, further that the

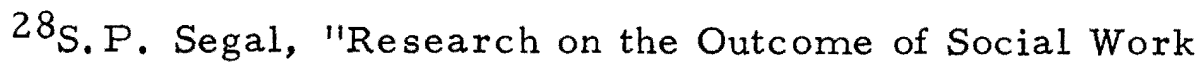
Therapeutic Interventions: A Review of the Literature, "Journal of Health and Social Behavior, 13 (March 1972): 3-17.

${ }^{29}$ David Mechanic and Edmund H. Volkart, "Stress, Illness Behavior and the Sick Role," American Sociological Review, 26 (February 1961): $51-58$. 
sick person was exempt from normal social role obligations. 30

Inherent in the sick role concept is the obligation to try to get well, to seek technically competent help and to cooperate in the process of getting well. Parsons suggested that the social role of the sick person may motivate that person to seek medical care. ${ }^{31}$ Mechanic and Volkart, studying the relative influence of stress and the tendency to adopt the sick role upon frequency of known illness concluded that the tendency to adopt the sick role was the more powerful variable. ${ }^{32}$ Segall has analyzed Parson's sick role concept and concluded that there was no operational definition of the sick role, there was precise means of measurement. ${ }^{33}$ However, Brown and Rawlinson, in concluding a detailed study on "Relinquishing the Sick Role Following Open-Heart Surgery," list various behavioral manifestations of the sick role: taking medications, proneness to bed rest, frequency of visits to the doctor, failure to fulfill normal responsibilities and roles, self-imposed restrictions on activity,

${ }^{30}$ Talcott Parsons, The Social System, (New York: The Free Press, 1951): 428-473.

31 Ibid.

${ }^{32}$ Mechanic and Volkart, p. 51.

${ }^{33}$ Alexander Segall, "The Sick Role Concept: Understanding Illness Behavior, "Journal of Health and Social Behavior, 17 (June 1976): 163-170. 
dependency on others for help with activities of daily living. ${ }^{34}$ They suggest further research into the se behavioral manifestations of the sick role. The Brown/Rawlinson study explained the important role counselling might play in encouraging the early relinquishment of the sick role:

Counseling would appear appropriate to foster greater independence and activity, might extend to the families and might well enlist the help of various professionals expert in inducing behavioral and attitudinal changes. 35

Part of the role of a medical social worker is counselling aimed at behavioral and attitudinal changes. The purpose of our study is to measure changes, if any, between patients' use of medical services before and after social work intervention. Given the complicated emotional-attitudinal influences on physical illness, would social work intervention aimed at the se psychosocial components have an effect on the behavioral manifestations of patients suffering from physical illness? More specifically, would patients' physician contacts, visits and phone calis, rates of hospitalizations, use of the emergency room and prescription drugs change after intervention by a medical social worker?

${ }^{34} \mathrm{Julia}$ S. Brown and May Rawlinson, "Relinquishing the Sick Role Following Open-Heart Surgery," Journal of Health and Social Behavior, 16 (March 1975):25. 
Another goal of the medical social worker in the outpatient clinic is coordination of care for patients referred. She often asks for a staffing of the physicians who have been involved in care of the patient. From this group, a primary physican is designated to follow the case. This study will look at the number of physicians involved in care of a patient before and then after social work intervention.

Other studies have shown that more coordinated care efforts can bring about more appropriate use of resources and perhaps even superior health outcomes. ${ }^{36}$ Donabedian reviews coordination of care efforts and cites several studies. 37 Koplin, et al, report that when patients with a history of repeated hospitalizations, under the care of many specialists, were assigned to one internist who acted as managing physician, hospital use was reduced by almost one-half. $^{38}$ Simon reports that when a sample of patients was assigned to a comprehensive care clinic and compared to those who

${ }^{36}$ Avedis Donabedian, "Models for Organizing the Delivery of Personal Health Services and Criteria for Evaluating Them," The Milbank Memorial Fund Quarterly, 50 (October 1972): 103154.

37 Ibid.

${ }^{38}$ A. V. Koplin, R. Hutchinson, and B.K. Johnson, "Influence of a Managing Physician on Multiple Hospital Ad missions," American Journal of Public Health, 49 (September 1959) 1174-1180, as cited by Donabedian, p. 136 . 
attended the more traditional multispecialty clinics of the outpatient department, the former made fewer visits, yet experienced greater improvement in their physical condition. ${ }^{39}$ Walker, et al, report that when outpatient care was provided by a coordinated team approach, the number of clinic visits was reduced, hospitalization used less frequently, fewer physicians were involved in the care of any one patient, and patient satisfaction was somewhat higher. ${ }^{40}$ This study will not be measuring patient satisfaction or well-being but only patient illness related behavior as measured by their use of the Kaiser medical system before and after social work intervention.

${ }^{39}$ A. J. Simon, "Social Structure of Clinics and Patient Improvement, "Administrative Science Quarterly, 4 (September 1959): 197-206, as cited by Donabedian, p. 136.

${ }^{40}$ E. B. Walker, B. Murawski, and G. W. Thorn, "An Experimental Program in Ambulatory Medical Care," New England Journal of Medicine, 271 (July 1964): 63-68, as cited by Donabedian, pp. $136-37$. 


\section{CHAPTER III}

\section{METHODOLOGY}

$\underline{\text { Research Design }}$

The primary purpose of this research project was to determine whether or not possible relationships existed between patient utilization of various services provided by the Kaiser Health Care System and the intervention by a medical social worker. If possible relationships existed, were they positive or negative, that is, was utilization of health care service increased or decreased with the intervention of social services? What services experienced the greatest reduction and which the least? Did changes vary by number of social work contacts?

In order to answer the questions posited by this study, a descriptive research design was used. Experimental designs with control groups or pre and post testing were unsuitable in this medical setting. For ethical reasons, a control group that would be denied service was not an option. A descriptive design that entailed medical record review offered the advantages of: using a behavioral measure of sick-role behavior with improvement being decreased utilization; yielding the largest number of cases for 
examination within the time available; and not interfering with ongoing social work practice.

\section{Sources of Data}

The patients'medical records, commonly referred to as "the chart," containing all the recorded contact and use of the Kaiser Health Care System by the patients were the primary source of data. Specifically, the time frame for data collection in each case was three months before and three months after initial social work intervention. After reading the social work notes in the chart and in a few cases referring back to separate records kept by the social worker, the time frame used in this study was determined to be the most appropriate and productive.

An alternative time frame would have been to use the calendar year 1976, but this would not have given comparable pre and post intervention periods for patients seen at different times of the year. A larger time frame was rejected because the position of outpatient clinic social worker was created and filled in March of 1976 and data collection began in January 1977. Therefore, a six-month pre and post period would have yielded very little data after the second six month period due to so few patients. The three-month pre/post model also reduced the time necessary to review each chart. 
To gain access to the data, it was necessary to obtain the medical record: The researchers were given sanction by the Kaiser Social Work Department to request and review patients' medical records.

\section{Research Instrument}

The research instrument was a logically constructed form suggested by the quantitative nature of the data such as numbers of clinic visits by each patient. A form had the advantage over laborious and confusing note-taking from the charts, and served to limit data collection to pertinent contacts. This Individual Data Sheet, represented below on Table I, was divided into eleven columns. Starting from the left, the first column was the date; the second, office visits with a physician or physician's assistant; the third, was labled " $R x$ " and referred to prescriptions that were written at the time of the office visit. The next two columns, numbers four and five, were telephone calls made by the patient to Kaiser and the "Rx" for any prescriptions given in response to that telephone call. Columns six and seven refer to Emergency Room (ER) visits and if a prescription was given there. Columns eight and nine refer to hospitalizations (HOSP) and " $\mathrm{Rx}$ " for any prescriptions written upon discharge. The tenth column was reserved for patients who "did not arrive" (DNA) for scheduled 
appointments. The last column, "other", was used to show any miscellaneous use of physician time as recorded in the chart. Notes that were made in the "other" column mainly consisted of letters and insurance forms the physicians wrote for patients. A further use of the "other" column was the recording of social work contacts.

\section{TABLE I}

INDIVIDUAL DATA SHEET

$\begin{array}{ll}\text { Name: Sue Doe } & \text { Age: } 40 \\ \text { Chart \#: } 00-11-12 & \text { DOB: } 11-22-36\end{array}$

Date* Office Visits $\mathrm{Rx}$ TC $\mathrm{Rx}$ ER $\mathrm{Rx}$ Hosp $\mathrm{Rx}$ DNA Other

\begin{tabular}{l|l|l|l|l|l|l|l|l|l|l}
\hline $3 / 26$ & Smith & & & & & & & & & \\
\hline $4 / 01$ & & & & & & & & & & \\
\hline $5 / 09$ & Dr. ? & & & & & & & & & \\
\hline $5 / 10$ & & & & & & & $\begin{array}{c}\text { Back-pain } \\
5 / 10\end{array}$ & & \\
\hline $5 / 25$ & & & & & & & $\begin{array}{c}\text { to } \\
5 / 12\end{array}$ & & & \\
\hline $6 / 20$ & Smith & & & & & & & & & \\
\hline \hline
\end{tabular}

*All dates are in the calendar year 1976

In Table I, the patient was seen by Dr. Smith on March 23, 1976 and received a prescription. On April 1, six days later, Sue Doe went to the Emergency Room and got a prescription there. Then on May 9, twenty-two days later, another clinic visit occurred 
with a physician whose name was undecipherable. For this study, a system was designed whereby illegible physician signatures were coded. In each chart the first such signature was coded Dr. ? ${ }^{1}$. As shown in the illustration when a patient had been hospitalized, the admission and discharge dates were noted as well as a brief statement of the reason for the hospitalization. In the sample, back pain was listed, a presentative diagnosis among those in the study who were hospitalized.

When the first contact with the social worker was noted, this was marked on the form simply with the date and the worker's name entered in the "other" column on the far right.

A second research instrument, the Category Data Sheet, represented in Table II, was constructed to gather individual and aggregate data on the number and frequency of social work contacts. Social Work contacts were divided into three categories. Category One represented Social Evaluation, and included all patients who had seen the social worker only once. Category Two

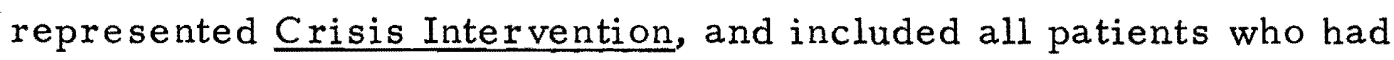
seen the social worker two or three times. Category Three represented Counselling, and included all patients who had seen the social worker four or more times.

The Category Data Sheet has seven columns. The first was the patient's name; the second, office visits; the third, physicians 
seen; the fourth, telephone calls; the fifth, Emergency Room visits; the sixth, hospitalizations; and the seventh, prescriptions.

TABLE II

CATEGORY DATA SHEET

\begin{tabular}{|c|c|c|c|c|c|c|c|}
\hline \multicolumn{8}{|c|}{ Category One } \\
\hline Patient's $N$ & me & Dr. Visits & \# of Dr. & TC & ER & Hospital & $\mathrm{Rx}$ \\
\hline \multirow[t]{2}{*}{ Sue Doe } & B & 2 & 2 & 0 & 1 & 1/3 Days & 3 \\
\hline & $\mathrm{A}$ & 1 & 1 & 0 & 0 & 0 & 0 \\
\hline \multirow{2}{*}{ Fred Day } & $\mathrm{B}$ & 6 & 5 & 3 & 0 & 0 & 8 \\
\hline & $A$ & 1 & 1 & 0 & 0 & 0 & 1 \\
\hline
\end{tabular}

All numbers represent individual patient totals.

All patients in the first category, Social Evaluation, were entered on Category Data Sheets marked Category One at the top. Then each patient's totals were entered across two lines: line "B" for before social work intervention totals, and Line "A" for after totals. In the space for hospitalization totals, two figures were included. The first, the total number of hospitalizations; the second, the total number of days hospitalized. (For example, Sue Doe had one hospitalization for three days: charted $1 / 3$ days). At the bottom of each sheet, subtotals were computed to aid accuracy in figuring the grand totals for each category. 
Pilot Study

A pilot study was conducted to determine the worthwhileness of this research project, and to test the clarity and effectiveness of the items on the research instrument. A purposive sample of three selected patient records was provided by the social worker whose caseload would be subsequently used as the universe from which the research sample would be drawn. These cases were selected because they possessed similar characteristics to the research sample.

The medical records of the three patients were identified and read thoroughly. Every contact and use of the Kaiser Health Care System by the se patients over the one year period, January 1 to December 31, 1976, was recorded by the researchers. More variables were examined in the pilot study than were used in the actual study. Among some of the unused variables were mental health visits, physical therapy treatments and particulars of prescriptions.

It was found in all three cases that there was a change in the pattern of utilization of Kaiser after the initial social work intervention. The change, in these few cases, was consistently a decrease in utilization. In the most dramatic case the decrease was $85 \%$ fewer physician contacts, a measure that included office visits, telephone calls and emergency room visits. 
Subsequent to the pilot study, appropriate adjustments were made to the research instrument. Narrowing the time frame from a one-year period to a three-month pre and post model was made in recognition of time limitations. A more precise definition of initial intervention was developed. To constitute initial intervention, a contact required patient-worker interaction. The first "in-person" interview was considered the point of intervention. However, telephone contacts were considered initial intervention if the call involved more than appointment setting, and actually dealt with aspects of patient problems.

The variety and duration of intervention by the social worker, elucidated by the pilot study, suggested discrimination between those who had been seen only once and those who needed several sessions before the case was closed. After the data pertaining to the schedule items was collected, it was sorted and placed into the three categories mentioned above. Social Evaluation, one contact with the social worker; Crisis Intervention, two to three contacts; and Counselling, four or more contacts.

\section{Data Collection}

A total of 175 cases was included in this study. To be eligible, a case had to meet all the criteria listed below:

1. Patient referred to the social worker. 
2. The case opened, i.e., intervention begun and written records kept.

3. The case closed in 1976.

4. The initial contact had been three months prior to the time when data was collected.

In 1976, a total of 212 cases were closed by the social worker in the out-patient clinic. Of these, 26 were ineligible for this study because they did not meet the three-month post intervention criteria when the data was collected, January through March, 1977. Seven cases were ineligible due to lack of direct contact with the social worker, and four cases were never obtained because their patient's medical records were in such constant use.

The individual Data Sheet proved to be well-suited to the task and served to reduce the amount of time required to review each chart as well as organize data by schedule item. The charts were the major obstacle to data collection. Not only were they difficult to obtain, but also to retain once they were in our possession. Since the charts are the patient's medical record, and since a multiplicity of disciplines and professionals use the charts, access to them is sometimes difficult. In addition to the problems of tracking, obtaining, and retaining records, there were a myriad of problems associated with the contents of these charts. First, notations were barely legible and sometimes completely illegible. Naturally, this 
was not conclusive to accurate tracking. Secondly, the notes were often out of time sequence, sometimes as much as a year's discrepancy existed.

Part of the problem in securing the charts was due to the fact that when chart request slips from the social work department were received by the record room, they were not routed through the computer. The advantage of the computer system was that the requests were attached to the chart, wherever it was; therefore, when the chart was returned, it automatically continued on to the requesting department. The omission of social work requests from the computer system was discovered after a number of requests was submitted but no response followed. It was ascertained that the se requests had been lost in interdepartmental mail en route to the regional record room. After inquiry by the researchers, social work requests were routinely computerized.

The strategy used to retrieve records was that of the "good guy-bad guy" model in which the total impact was to get desired results, i.e., the charts, without offending anyone. One researcher would go and demand the charts, cite our rights and sanction to do so and sternly inquire about delays. Whereas, the other researcher would be pleasant, sociable and understanding about the nuisance these two-bundred extra chart requests created.

The legibility of the charts was a major concern. Becoming 
highly skilled at detection was mandatory to collect data from the large number of charts in the study. The Individual Data Sheet helped eliminate the need to read every work written. For example, in the case of a clinic visit, the clinic stamp and the date alerted the researcher that this was a doctor visit, and a glance at the signature indicated which name would be listed on the form. If a physician's signature was unreadable, a thorough review of the chart for similar marks with the name stamped below sometimes prevented coding as Dr. ${ }^{x}$. When a signature was not legible by any means, then it was coded as Dr. ${ }^{1}$. If there were other undecipherable signatures, different in style from the first, indicating a second physician, then this was coded as Dr. ${ }^{2}$, and so on for as many Dr. ${ }^{x_{1}}$ s as needed. Sometimes part of the name could be made out. In these cases, referring to the clinic stamp and then consulting a sheet published daily by Kaiser listing the availability of physicians by clinic might show there was only one physician at the clinic with a name starting or ending with a particular letter.

After identifying the physician, the researcher looked at prescription pattern with the origin the important factor. This tracking of prescriptions by source of origination was determined to be too complicated to utilize and draw reasonable conclusions. Therefore, when the information was tallied for each case a single figure, the total number of prescriptions written from all locations before 
and after social work intervention, was computed.

When the Individual Data Sheets were completed, a red line was drawn across the sheet at the point of initial social work intervention. This facilitated totaling the before (above the red line) and after (below the red line) data. These totals were entered in the appropriate column at the base of each individual sheet and recorded on the Category Data Sheets.

\section{Limitation of Study}

The major limitations of this study revolved around two issues: namely, the time frame and sample selection. The time frame was limited to a six-month period - three months before and three months after social work intervention. Since many patients' medical histories reflected years of intensive use of the Kaiser Health Care System, a six-month analysis of the system may not reflect any significant long-term trend or hold any useful predictive values. Additionally, there was an overlapping of the post-treatment time period with the concurrent treatment of patients in Categories I and II by the social worker. Since the social worker had knowledge of the research, it is assumed that some bias was introduced into the treatment process. The degree and direction of this bias is not known.

The sample was selected from the closed cases of the out- 
patient clinical social worker!s caseload. Therefore, the subjects were selected purposively and not on the basis of representativeness. Generalizations from the findings to other populations beyond the Kaiser Health Care System are not recommended.

There was also a problem with the number of cases represented in each category. Because of the nature of the sample, there could not have been an equal distribution of subjects in the three category analytic frame. Therefore, the categories were limited in their ability to establish relationships and inter-category comparisons.

However, in spite of these limitations of validity and reliability, the major task of the research was accomplished; that is, to identify possible relationships between social work intervention and utilization of health care services, and to identify areas for future research. 


\section{CHAPTER IV}

\section{RESULTS AND FINDINGS}

The research problem for this study was to identify possible changes in the pattern of patient utilization of the Kaiser Health Care System associated with services provided by an outpatient clinic social worker. The sample was 175 closed cases selected from the outpatient clinic social worker's inactive caseload. Comparisons were made between the utilization rate of Kaiser three months before and three months after initial social work intervention. Data were collected from each patient's medical record pertaining to numbers of office visits, different physicians seen for office visits, telephone calls, emergency room visits, hospitalizations and prescriptions. Individual patient totals for these items were sorted and placed into three categories based on the number of social work contacts they had received.

The categories of social work intervention were referred to

as: 1) Social Evaluation; 2) Crisis Intervention, and 3) Counseling. The first Category, Social Evaluation included those cases with only one social work contact. There were 100 cases in this category. The second Category, Crisis Intervention, included cases with two 
to three social work contacts. There were 62 cases in this category. The third Category, Counselling, included cases with four or more social work contacts. There were 13 cases in the third Category.

Table III presents descriptive data on age and six for the three categories representing the sample.

TABLE III

AGE AND SEX OF THE SAMPLE

\begin{tabular}{|c|c|c|c|c|}
\hline \multirow[t]{2}{*}{ CATEGORY } & \multicolumn{2}{|c|}{ SEX } & \multicolumn{2}{|c|}{$\mathrm{AGE}$} \\
\hline & Male & Female & & \\
\hline \multirow{3}{*}{$\begin{array}{c}1 \text {-Social } \\
\text { Evaluation } \\
n=100\end{array}$} & 43 & 57 & Range & $3-82$ \\
\hline & $43 \%$ & $57 \%$ & Modal age & 56 \\
\hline & & & Median age & 42 \\
\hline \multirow{3}{*}{$\begin{array}{c}2-C \text { risis } \\
\text { Intervention } \\
n=62\end{array}$} & 29 & 33 & Range & $15-88$ \\
\hline & $46.8 \%$ & $53.2 \%$ & Modal age & 34,58 \\
\hline & & & Median age & 42 \\
\hline \multirow{3}{*}{$\begin{array}{c}3 \text {-Counselling } \\
n=13\end{array}$} & 6 & 7 & Range & $26-65$ \\
\hline & $46.2 \%$ & $53.8 \%$ & Modal age & 26,40 \\
\hline & & & Median age & 38 \\
\hline \multirow{3}{*}{$\begin{array}{l}\text { Total } \\
n=175\end{array}$} & 78 & 97 & Range & $3-88$ \\
\hline & $44.6 \%$ & $55.4 \%$ & Modal age & 56 \\
\hline & & & Median age & 42 \\
\hline
\end{tabular}

There were more women than men in each category and the sample as a whole had about 10\% more women. Category 1 had the 
largest range in age, from 3 to 82 , and an even distribution of ages with 42 as the median, therefore equal numbers of cases older and younger. The range in ages was slightly smaller for Category 2, spanning 73 years from age 15 to 88 . Again the median age was 42 but two ages, 34 and 58, tied for modal age. The third Category was generally younger, the oldest case being 65 . The range was only 26 to 65 and the median age was down to 38 . Two figures were most frequently occurring, thus the modal ages were 26 and 40 . For the entire sample the overall range was 85 years, from age 3 to 88 . The median age was 42 and the modal age was 56.

To analyze the data, a set of specific research questions was developed. Each question dealing with a component of services utilized. Where appropriate, tables were designed to summarize findings. Summarized case studies were also included to illustrate the variety of clients and interventions that comprised the practice of the outpatient clinic social worker.

The first question dealt with patient visits. "Is social work intervention associated with a difference in the rate of clinic visits with doctors or physicians' assistants?" Table IV shows the number of office visits made by the sample during the three months pre and post initial social work intervention. The data are presented by category of social work contacts as well as for the entire sample. Since the changes in all cases were positive (decrease) the 
column for percent of change was labeled percent decrease for the tables listed in this chapter.

TABLE IV

NUMBER OF OFFICE VISITS FOR THE THREE MONTHS

BEFORE AND AFTER INITIAL SOCIAL WORK INTERVENTION

\begin{tabular}{c|c|c|c|c}
\hline \multirow{2}{*}{ CATEGORY } & \multicolumn{3}{|c}{ NUMBER OF OFFICE VISITS } \\
& Before & After & Difference & $\begin{array}{c}\text { Percent } \\
\text { Decrease }\end{array}$ \\
\hline $\begin{array}{c}\text { E-Social } \\
\text { n=100 } \\
\text { 2-Crisis } \\
\text { Intervention } \\
n=62\end{array}$ & 246 & 207 & 219 & $51.4 \%$ \\
\hline $\begin{array}{c}\text { 3-Counselling } \\
n=13\end{array}$ & 49 & 138 & 109 & $44.1 \%$ \\
\hline $\begin{array}{c}\text { Total } \\
n=175\end{array}$ & 722 & 37 & 12 & $24.5 \%$ \\
\hline \hline
\end{tabular}

It appears that social work intervention is associated with a change in rates of office visits. The Social Evaluation Category, which included those cases of only one social work contact, showed the sharpest decline with a $51.4 \%$ decrease. The rate of decrease was progressively smaller, but still dramatic, as the number of social work contacts rose, thus $44.1 \%$ for the two to three contact 
group referred to as Crisis Intervention and $24.5 \%$ for the Counselling group with four or more social work contacts.

The case of WD is an example of only one social work contact followed by a sharp decrease in office visits. This was due to the social worker's referral to a more appropriate community resource. Mr. D. was a thirty-eight-year-old, obese man who worked as a machine operator. He had a history of recurrent back problems which was aggravated by the heavy lifting at his job. For the three months before social work intervention this patient saw seven different physicians a total of eleven time.

After he was referred to the social worker for an evaluation, her notes read that he was "under no emotional stress, no depression ... Will accept referral to the Workman's Compensation Disability Prevention Center." Thus, he was referred to an appropriate source for the help he really needed.

For the three months after social work intervnetion this patient saw one Kaiser physician one time only. He later called the social worker to report he had found help at the rehabilitation center.

The second research question addressed the issue of number of physicians seen for office visits during the three months before and after initial social work intervention. Table $\mathrm{V}$ gives the data totals by category.

There appears to be a decrease in the number of physicians seen for office visits associated with the provision of social work services in the outpatient clinic. Again there are dramatic declines with the strongest trend in the social evaluation group. However, the percent of decrease is not so widely varied between the categories 
TABLE V

NUMBER OF PHYSICIANS SEEN FOR THREE MONTHS

BEFORE AND AFTER INITIAL SOCIAL WORK

INTER VENTION

\begin{tabular}{|c|c|c|c|c|}
\hline \multirow{2}{*}{ CATEGORY } & \multicolumn{4}{|c|}{ NUMBER OF PHYSICIANS SEEN } \\
\hline & Before & After & Difference & $\begin{array}{l}\text { Percent } \\
\text { Decrease }\end{array}$ \\
\hline $\begin{array}{c}1 \text {-Social } \\
\text { Evaluation } \\
n=100\end{array}$ & 283 & 134 & 149 & $52.7 \%$ \\
\hline $\begin{array}{c}2-C \text { risis } \\
\text { Intervention } \\
n=62\end{array}$ & 154 & 85 & 69 & $44.8 \%$ \\
\hline $\begin{array}{c}3 \text {-Counselling } \\
n=13\end{array}$ & 34 & 23 & 11 & $32.4 \%$ \\
\hline $\begin{array}{l}\text { Total } \\
n=175\end{array}$ & 471 & 242 & 229 & $48.6 \%$ \\
\hline
\end{tabular}

since the spread is $20.3 \%$ in this table versus $26.9 \%$ for numbers of office visits in Table IV. It is generally held that coordinated care, provided by a primary physician on a consistent basis, with appropriate referrals to specialists as needed, is better health care. The trend of this sample to see fewer physicians would suggest that they were receiving better care.

The case of $C G$ is one where a patient tried several physicians and was still dissatisfied until the social worker assisted with a 
medical referral.

Mrs. G. is a 45-year-old, married, mother of four children. Her husband is a legal clerk supervisor and she is on social security disability due to childhood polio. She has had multiple surgical procedures on her right foot.

In March of 1976, she saw an orthopedist for pain in her left foot and he recommended surgery. During the six months between March and August, 1976, she saw five different physicians a total of five times, expressing much anxiety over her foot problems.

In August she saw the social worker and was able to vent her anxiety and her disagreement with the orthopedist regarding surgery on her left foot. The social worker set up a consultation with the physiatrist for the patient.

During the six months between August and January, 1977, the patient saw only two physicians a total of four times. She saw the physiatrist in September and a new orthopedist in October and November. Surgery was scheduled for January and Mrs. G. was then reconciled to the need for the operation.

Question three: Is social work intervention associated with

a difference in the rate of telephone contacts? The results are shown in Table VI.

It appears there is a difference in the rate of telephone contacts after initial social work intervention. In this case the largest improvement came in the crisis intervention category with a $44.3 \%$ decrease over the three-month pre social work intervention time period. Category 3, Counselling, shows one of the smallest rates of change in this study. A single case with an abnormally 
TABLE VI

NUMBER OF TELEPHONE CONTACTS FOR THREE MONTHS BEFORE AND AFTER INITIAL SOCIAL WORK INTER VENTION

\begin{tabular}{c|c|c|c|c}
\hline \multirow{2}{*}{ CATEGORY } & \multicolumn{2}{|c}{ NUMBER OF TELEPHONE CONTACTS } \\
& Before & After & \multicolumn{2}{c}{ Difference $\begin{array}{c}\text { Percent } \\
\text { Decrease }\end{array}$} \\
\hline $\begin{array}{c}\text { E-Social } \\
\text { n=100 }\end{array}$ & 111 & 81 & 30 & $27.0 \%$ \\
\hline $\begin{array}{c}\text { 2-Crisis } \\
\text { nntervention } \\
n=62\end{array}$ & 79 & 44 & 35 & $44.3 \%$ \\
\hline $\begin{array}{c}3-\text { Counselling } \\
n=13\end{array}$ & 28 & 25 & 3 & $10.7 \%$ \\
\hline $\begin{array}{c}\text { Total } \\
n=175\end{array}$ & 218 & 150 & 68 & $31.2 \%$ \\
\hline
\end{tabular}

high rate of telephone contacts in Category 3 altered the percentage of change from what would have been an $8.3 \%$ increase to the $10.7 \%$ decrease shown in the table.

The following case illustration is that of $A B$, a category one patient, who demonstrates large decreases in utilization of various services and a slight improvement in telephone contacts. This case and others like it may account for the Social Evaluation Category showing a smaller percent of decrease. The social work 
intervention in this case was a team conference, with the patient

present, aimed at coordination of care.

$A B$, a forty-nine-year-old woman with a history of back pain, had a record of extensive use of the Kaiser Health Care System. From July, 1970, to April, 1976, she had 13 hospitalizations, 32 emergency room visits, 311 outpatient contacts with 66 different physicians.

The patient was referred to the social worker in April of 1976 by the orthopedist who noted her problem as "emotional, not medical." The social worker reviewed her medical chart and obtained the figures cited above on physician contacts and found many prescriptions had been given for Tylenol 4 (with codeine), meprobamate, norflex, darvon compound, etc.

The social worker called for a team conference of the medical doctor, the orthopedist, the psychiatrist, the homemaker, and the social worker. The team decided that only the primary physician would be responsible for prescriptions for this patient. The social worker would be available to help the patient handle feelings about decreasing her drug dependency if she so desired.

Following the team conference, the patient refused to see the social worker but her intensive use of the medical system did decrease. For the three months prior to the team conference she saw five physicians for a total of five times, made eleven telephone calls for ten prescriptions and was in the emergency room once. The three months after the team conference she had no office visits, eight telephone contacts for seven prescriptions and made no emergency room visits.

Data with regard to the number of prescriptions written

during the three months before and after initial social work intervention were collected to answer the question, "Is social work intervention associated with a difference in the rate of prescriptions written?"' The results are shown in Table VII. 
TABLE VII

NUMBER OF PRESCRIPTIONS FOR THREE MONTHS BEFORE AND AFTER INITIAL SOCIAL WORK

INTER VENTION

\begin{tabular}{|c|c|c|c|c|}
\hline \multirow[b]{2}{*}{ CATEGORY } & \multicolumn{4}{|c|}{ NUMBER OF PRESCRIPTIONS } \\
\hline & Before & & Difference & $\begin{array}{l}\text { Percent } \\
\text { Decrease }\end{array}$ \\
\hline $\begin{array}{c}1 \text {-Social } \\
\text { Evaluation } \\
n=100\end{array}$ & 242 & 119 & 123 & $50.8 \%$ \\
\hline $\begin{array}{c}2-C \text { risis } \\
\text { Intervention } \\
n=62\end{array}$ & 162 & 75 & 87 & $53.7 \%$ \\
\hline $\begin{array}{c}3-\text { Counselling } \\
n=13\end{array}$ & 34 & 31 & 3 & $8.8 \%$ \\
\hline $\begin{array}{l}\text { Total } \\
n=175\end{array}$ & 438 & 225 & 213 & $48.6 \%$ \\
\hline
\end{tabular}

It appears that social work intervention is as sociated with a decrease in the number of prescriptions written. The first two categories, Social Evaluation and Crisis Intervention, show decreases of $50.8 \%$ and $53.7 \%$. However, the third Category, Counselling, shows the smallest change of the study with only $8.8 \%$ decrease in the three months post initial intervention. It should be pointed out that during the three months post intervention period, some patients in the Counselling Category were still in treatment 
with the social worker. These patients tended to have more serious and chronic problems, including addiction to narcotic pain medications, which made treatment of any kind more difficult; hence, improvement and/or recovery rates were more gradual and less impressive than the other categories.

The figures for all prescriptions do not reveal those cases where a prescription medication was changed to a weaker, nonnarcotic substitute, nor is there information regarding the number of unit doses prescribed. Two prescriptions written before and two after initial intervention may represent very different circumstances. To give an extreme example, the first two prescriptions could have been for 100 tablets of Tylenol 4 (tylenol with codeine), with three refills authorized each time the prescription was written. The second two prescriptions could have been for only 20 tablets of a mild tranquilizer such as Librium $10 \mathrm{mg}$. with no automatic refills. The point is that counting numbers of prescriptions written tells us very little about the use and abuse of medication; hence, no definite conclusions can be drawn about medication use associated with social work intervention.

The following case is that of a Category 3 patient and illustrates social work counselling for drug dependency.

GM is a 26-year-old man who was the victim of a high velocity gunshot wound in 1974. He had a difficult recovery and suffers from deformities around his 
shoulder joint, major soft tissue losses and a shoulder fusion.

The patient was referred to the social worker in April, 1976, for "alternatives to pills for pain." The medical chart revealed extensive prescriptions for percodan, a narcotic, and the patient admitted to being addicted. The social worker reviewed some personal history with the patient and assessed that he had never done grief work connected with his accident. The patient expressed a fear of going insane and readily agreed to counselling.

Mr. M. saw the social worker twice a week for three weeks and once a week for several more weeks. He worked through his fears and guilt over the accident; the gunshot wound had been self-inflicted. He was seen with his wife during some of the sessions and they worked together on communication and validation. During this time, the patient reduced his percodan intake and was gradually weaned to milder pain medications and tranquilizers.

During the three months prior to social work intervention the patient made a total of four office visits to two different physicians, three emergency room visits, seventeen telephone calls obtaining seventeen prescriptions and was in the hospital once for seven days. For the three months post initial intervention he made no office or emergency room visits. He did make thirteen telephone calls for thirteen prescriptions, but these prescriptions were for smaller dosages of milder drugs.

When the social worker made a follow-up telephone call two months after closing the case, the patient reported he was pleased with his success at being off drugs two and one-half months; his morale was good and he was starting to attend a local community college.

Emergency room visits are the next topic for review. Table

VIII is presented on page 57 in answer to the question, "Is social work intervention associated with a difference in the rate of emergency room visits?" 
TABLE VIII

NUMBER OF EMERGENCY ROOM VISITS FOR THE THREE MONTHS BEFORE AND THREE MONTHS AFTER INITIAL SOCIAI WORK INTERVENTION

\begin{tabular}{|c|c|c|c|c|}
\hline \multirow{2}{*}{ CATEGORY } & \multirow{2}{*}{$\begin{array}{l}\text { NUMBER } \\
\text { Before }\end{array}$} & \multicolumn{2}{|c|}{ OF EMERGENCY ROOM } & \multirow{2}{*}{$\begin{array}{l}\text { VISITS } \\
\text { Percent } \\
\text { Decrease }\end{array}$} \\
\hline & & After & Difference & \\
\hline $\begin{array}{c}1 \text {-Social } \\
\text { Evaluation } \\
n=100\end{array}$ & 33 & 24 & 9 & $27.3 \%$ \\
\hline $\begin{array}{c}2-C \text { risis } \\
\text { Intervention } \\
n=62\end{array}$ & 22 & 9 & 13 & $59.1 \%$ \\
\hline $\begin{array}{c}3-\text { Counselling } \\
n=13\end{array}$ & 6 & 2 & 4 & $66.7 \%$ \\
\hline $\begin{array}{l}\text { Total } \\
n=175\end{array}$ & 61 & 35 & 26 & $45.3 \%$ \\
\hline
\end{tabular}

It appears that initial social work intervention is associated with a decrease in the rate of emergency room visits. The largest percent of decrease occurred in the category with the most social work contacts, that is, in the Counselling group which had four or more contacts. The decrease was $66.7 \%$. The percentage of decrease in emergency room visits was progressively smaller as the number of contacts with the social worker declined. Category 2, Crisis Intervention, declined to $59.1 \%$, and Category 1, Social Evaluation to $27.3 \%$. 
It is possible to generalize that the counselling cases which required more social work contacts were more likely to use the emergency room during the three months prior to social work intervention and appear to show the greatest decrease in the three months post initial intervention.

The case of $\mathrm{BK}$ illustrates short term counselling around emotional depression and physical symptoms with an associated improvement and decrease in utilization including a decrease in emergency room visits.

$\mathrm{BK}$ is a 26 -year-old housewife with a three-yearold son. She has a thick medical record from many physician contacts with various presenting problems, such as headaches, nervous tension, chest pains, severe menstrual cramps, weakness, lack of energy, and sleeplessness.

During the three months prior to social work intervention this patient made contact with seven different physicians, in six office visits, made three telephone calls, three emergency room visits, obtained nine prescriptions for pain medications containing codeine plus several demerol injections.

She was referred to the social worker in October for counselling. The social worker noted after the first interview that the patient was "very depressed, (had) low self-esteem." The patient claimed she had no reason to feel as she did. Mrs. K. and the social worker agreed to work on the identification and validation of feelings for the following two weeks. Three sessions followed in which they worked through the patient's feelings of insecurity, lack of confidence and fear of hurting others, including her domineering mother and husband.

In the three months after initial social work 
intervention, this patient saw one physician once, for a cold and sore throat. She made no emergency room visits, telephone calls, and obtained no prescriptions. The social worker made two follow-up telephone calls in which the patient reported feeling much better.

The next research question dealt with hospitalization. Is social work intervention associated with a difference in the frequency and duration of hospitalizations? The subject of hospitalizations involved several factors relating to frequency and duration, these were included in Table IX, represented on page 60, as number of hospitalizations, the length of stay and the average length of stay. For Category 1, Social Evaluation, the number of hospitalizations decreased by $53.8 \%$, the length of stay decreased by $71.7 \%$, and the average length of stay went down by $39.1 \%$. Clearly the three months after initial intervention had fewer hospitalizations of shorter duration.

In Categories 2 and 3, Crisis Intervention and Counselling, the decrease in hospitalizations was $100 \%$ as none of the se patients we re admitted to the hospital during the three months post initial intervention.

Although the percentages of decline in hospital utilization were very dramatic, it should not be concluded, categorically, that social work intervention reduces hospitalization by $100 \%$. Because of the small " $\mathrm{N}$ " and uneven distribution of patients in each category 
TABLE IX

HOSPITALIZATIONS FOR THREE MONTHS BEFORE AND AFTER INITIAL SOCIAL WORK INTER VENTION

\begin{tabular}{|c|c|c|c|c|}
\hline \multirow{2}{*}{\multicolumn{2}{|c|}{ CATEGORY }} & \multicolumn{3}{|c|}{ HOSPITALIZATIONS } \\
\hline & & \multirow{2}{*}{$\frac{\text { Number }}{13}$} & \multirow{2}{*}{$\begin{array}{c}\begin{array}{c}\text { Length } \\
\text { of } \\
\text { Stay }\end{array} \\
113\end{array}$} & \multirow{2}{*}{$\begin{array}{l}\begin{array}{l}\text { Average } \\
\text { Length of } \\
\text { Stay* }\end{array} \\
8.7\end{array}$} \\
\hline \multirow{4}{*}{$\begin{array}{c}1 \text {-Social } \\
\text { Evaluation } \\
n=100\end{array}$} & Before & & & \\
\hline & After & 6 & 32 & 5.3 \\
\hline & Difference & 7 & 81 & 3.4 \\
\hline & $\begin{array}{l}\text { Percent } \\
\text { Decrease }\end{array}$ & $53.8 \%$ & $71.7 \%$ & $39.1 \%$ \\
\hline \multirow{5}{*}{$\begin{array}{c}2-C \text { risis } \\
\text { Intervention } \\
n=62\end{array}$} & Before & 4 & 25 & 6.3 \\
\hline & After & 0 & 0 & 0 \\
\hline & Difference & 4 & 25 & 6.3 \\
\hline & Percent & & & \\
\hline & Decrease & $100 \%$ & $100 \%$ & $100 \%$ \\
\hline \multirow{4}{*}{$\begin{array}{c}3-\text { Counselling } \\
n=13\end{array}$} & Before & 1 & 7 & 7.0 \\
\hline & After & 0 & 0 & 0 \\
\hline & Difference & 1 & 7 & 7.0 \\
\hline & $\begin{array}{l}\text { Percent } \\
\text { Decrease }\end{array}$ & $100 \%$ & $100 \%$ & $100 \%$ \\
\hline \multirow{4}{*}{$\begin{array}{l}\text { Total } \\
\mathrm{n}=175\end{array}$} & Before & 18 & 145 & 8.1 \\
\hline & After & 6 & 32 & 5.3 \\
\hline & Difference & 12 & 113 & 2.8 \\
\hline & $\begin{array}{l}\text { Percent } \\
\text { Decrease }\end{array}$ & $66.7 \%$ & $77.9 \%$ & $34.6 \%$ \\
\hline
\end{tabular}

*The average length of stay in 1976 for all Kaiser patients was 46 days. 
predictive values and/or generalizations should be guarded. However, there does appear to be a trend toward reduced hospitalizations for the whole sample with the number of admissions down $66.7 \%$, the length of stay down $77.9 \%$, and the average length of stay down $34.6 \%$.

In spite of the marked decreases shown, patients who were referred to the social worker still had a longer average length of stay than the average Kaiser patient. For all patients hospitalized at Kaiser in 1976, the average length of stay was 4.6 days in contrast to the average length of stay for the sample which was 5.3 days before, and 5.3 after social work intervention. Therefore, after social work intervention length of hospital stay for the sample came within .7 days of the average patient hospitalization at Kaiser.

The case of OS is that of a Category 2 client who had one hospitalization of seven days before and none after social work intervention. It also illustrates the complicated interaction of marital stress, tension, and back pain.

OS is a moderately obese 43-year-old woman who works as a secretary and is married to a mechanic. They have three children, 23, 19, and 11 years old. She smokes two packages of cigarettes and drinks five cups of coffee a day. Occasionally she uses alcohol. In 1972, she had a hysterectomy and has had some history of low back problems. In January, 1976, she fell at home and injured her lower back.

Between January and July, 1976, Mrs. O saw five different physicians a total of 14 times. She had numerous physical therapy treatments and was given a variety of prescriptions, these were muscle relaxants, pain 
killers, and tranquilizers. In late March, she was hospitalized for seven days with low back pain. After traction and more physical therapy, there was a

"Mild improvement" but the orthopedist termed the prognosis "guarded." Further office visits and tranquilizers were not helpful; in July she reported that her back was worse. The physician noted "increased tension over family problems" and referred her to the social worker.

The first visit of this patient and her husband to the social worker ended abruptly when her husband walked out in a fury over the wife's statement that he put pressure on her. The patient saw the social worker the next time alone for a one-and-a-half hour session. The social worker noted, "Both patient and spouse able and willing to improve relationships. Good insight. Worked on communication skills and validation." Later followup telephone calls were made to the patient and her husband by the social worker. The couple reported much improvement in their relationship and the wife's health.

There was one physician contact in the three months following the initial social work intervention. It appears that a decrease in the marital stress led to a decrease in tension and back pain for this woman.

Summary

The purpose of this descriptive study was to ascertain if there was a difference in patient utilization of the Kaiser Health Care System associated with social work intervention. Table X portrays an over-all picture of the results. The vertical columns show the several areas of utilization employed in this study, and the horizontal axes the percentages of decrease by category. By having all the measures represented in one table, it should be possible to gain an understanding of the overall results. 
TABLE $X$

PERCENTAGE DECREASE IN UTILIZATION OF

SERVICES BY CATEGORIES

\begin{tabular}{c|c|c|c|c|c|c|c}
\hline & \multicolumn{5}{|c}{ SERVICES } \\
CATEGORY & OV & Phys. & TC & Rx & ER & Hosp & LOS \\
\hline $\begin{array}{c}\text { 1-Social } \\
\text { Evluation } \\
\text { n=100 }\end{array}$ & $51.4 \%$ & $52.7 \%$ & $27.0 \%$ & $50.8 \%$ & $27.3 \%$ & $53.8 \%$ & $71.7 \%$ \\
\hline $\begin{array}{c}\text { 2-Crisis } \\
\text { n=62 }\end{array}$ & $44.1 \%$ & $44.8 \%$ & $44.3 \%$ & $53.7 \%$ & $59.1 \%$ & $100 \%$ & $100 \%$ \\
\hline $\begin{array}{c}3-\text { Counselling } \\
\text { n=13 }\end{array}$ & $24.5 \%$ & $32.4 \%$ & $10.7 \%$ & $8.8 \%$ & $66.7 \%$ & $100 \%$ & $100 \%$ \\
\hline $\begin{array}{c}\text { Total } \\
n=175\end{array}$ & $47.1 \%$ & $48.6 \%$ & $31.2 \%$ & $48.6 \%$ & $45.3 \%$ & $66.7 \%$ & $77.9 \%$ \\
\hline \hline
\end{tabular}

OV - Office Visits

ER - Emergency Room Visits

\# Phys. - Number of Physicians seen

TC - Telephone Calls Hosp - Hospitalizations

Rx - Prescriptions LOS - Length of Stay

Clearly there does appear to be a marked change in utilization

patterns as all areas of services experienced a decrease in the three months post social work intervention. The largest mean decrease for the entire group occurred in the frequency and duration of hospitalizations, at $100 \%$. The smallest mean decrease for the whole sample was in the rate of telephone calls, at $31.2 \%$. However, 
this decrease is still a significant change.

By category, the largest percent decrease was the $100 \%$

improvement in the frequency and duration of hospitalizations for

Categories 2 and 3, Crisis Intervention and Counselling. The least

change was $8.8 \%$ in the number of prescriptions written for Category

3, Counselling, patients.

Category 1, Social Evaluation, shows decreases of over $50 \%$

in all areas of services, except for Emergency Room visits and Telephone Calls which showed the least improvement at $27.3 \%$ and $27.0 \%$ respectively. The largest decrease in utilization for Category 1 patients was in length of stay for hospitalizations, a decrease of $71: 7 \%$.

In Category 2, Crisis Intervention, with the exception of the two exceptionally large decreases of $100 \%$ for hospitalizations and length of stay, the percentages of decrease were more consistent, ranging from $44.1 \%$ to $59.1 \%$. The smallest percent of decrease for this category was in Office Visits at $44.1 \%$. The next two items, also related to outpatient clinic contacts, were quite similar at 44. $8 \%$ for Physicians seen for Office Visits, and $44.3 \%$ for Telephone Calls.

The third Category, Counselling, demonstrated the extremes of percent of change in this study. The largest percent of decrease was also the largest for all the categories at $100 \%$ for Hospitalizations 
and length of stay. The smallest percent of change was also the smallest in any of the categories at $8.8 \%$ for Prescriptions.

The rest of the measures did not seem to cluster around the 50 th percentile as did many of the measures in Categories 1 and 2 . It would seem that this counselling group with an " 11 " of only 13 was less predictable than the other categories. 


\section{CHAPTER V}

\section{CONCLUSIONS AND RECOMMENDATIONS}

\section{Conclusions}

Based on the results of this study, it appears that there is a definite relationship between social work intervention and patients' use of the Kaiser Health Care System. After adding a social worker to the health care team in one particular clinic, the results demonstrated a dramatic decline in the utilization of medical services. As a member of the health care team, the social worker's primary responsibilities were coordination of services and resources and the provision of direct counselling services to complement and enhance medical care. Although the social worker was involved in other aspects of patient care, the major areas of focus for this study were patient-physician contacts, including office visits, emergency room visits, telephone calls, prescriptions, and hospitalizations. For the research population of 175 subjects, social work intervention appeared to be positively associated with an over-all change rate of some 53 percent. This means that the utilization rates for the services indicated above were decreased by more than half. Specifically, social work intervention was associated with a 
47. $1 \%$ decrease in physician office visits; a $48.6 \%$ decrease in the number of physicians seen for office visits; a $31.2 \%$ decrease in telephone contacts; a $48.6 \%$ decrease in the number of prescriptions written; a $45.3 \%$ decrease in emergency room visits; a $66.7 \%$ decrease in frequency of hospitalizations and a $77.9 \%$ decrease in the average length of stay in the hospital.

In spite of the differential levels of contacts in the three categories of social work intervention, a decrease in utilization of health care services was found in each category. For example, in Category one, the social worker had only one contact with the patient, yet, there was a $47 \%$ average decrease in utilization of services. Categories two and three showed average decreases of $63 \%$ and $49 \%$ respectively.

Because this study was not an experimental design, cause and effect relationships cannot be claimed. However, the data support the hypothesis that social work intervention, aimed at the psychosocial components of physical illness, is associated with positive behavioral changes in patients' utilization of medical services.

This study demonstrates and reinforces the concept that medical care is more than symptom identification, diagnosis, and treatment. The needs of physically sick people are not always simple. The patient is not merely a symptom or an illness, but rather a dynamically whole person with a health problem. The help 
which the patient requires must be provided within a given framework involving the nature of the illness itself, the personality and idiosyncracies of the individual involved, the socio-cultural milieu of which the person is a part, and the personal, familial and community resources available to the patient. Therefore, the need for a comprehensive approach to treatment involving a team of professional and paraprofessional health care workers is mandatory.

Prior to the social worker's joining the health care team, many of the psychosocial needs of the patients, which hampered their ability to recover from their illnesses, were ignored. The physicians and other allied health professionals did not have the time to devote to assisting the patients in resolving the se personal problems because the medical needs demanded their full attention. The presence of a social worker provided the additional component in the comprehensive treatment approach.

It is apparent that a comprehensive approach to the patient, with emphasis on the inter-related psychological, social, emotional, and environmental aspects of physical illness, is positively associated with the patient's increased ability to cope with and recover from physical illness. By starting where the patient is, focusing on and accepting what the particular illness means to that individual patient, the social worker assesses human needs which may impact on the treatment of physical illness, and the patient's ability to 
accept and use treatment. After assessing the patient's social roles, emotional reactions, interpersonal relationships, environmental factors, and available resources, the social worker (in collaboration with the patient) decides on an appropriate social treatment plan. As mentioned in previous chapters, social work intervention includes a range of treatment plans: one time only contact for community resource referrals or a coordinated care plan; two to three sessions for crisis intervention-supportive reassurance aimed at reducing anxiety and stress, enabling a patient to deal with negative feelings and understand roles that may be altered because of physical illness. More extensive counselling is also offered around the various problems associated with sick-role behavior, marital and family difficulties, drug dependency, etc. Other studies have indicated that providing the patient with the opportunity to express his/her hopes and fears, and involving the patient in doing something about the stark realities with which he/she is living often makes the difference between recovery from illness and regression. Based on this study, the conclusion that social work intervention is positively correlated with decreased utilization of medical services, seems inescapable.

\section{Recommendations}

The goal of the Kaiser System is unified delivery of comprehensive health care services. It appears the addition of social work 
service not only extends the comprehensiveness of treatment, but aids in coordination, unification, and effective utilization. It has been shown that social work intervention is associated with decreased physician contacts, prescription rates, and hospitalizations. Not only is physician time saved but also that of nurses, pharmacists, and allied health personnel. Although an actual cost/benefit analysis was not attempted, it is apparent that the decreases in utilization associated with social work intervention are economically beneficial to the Kaiser system. It is strongly recommended that Kaiser increase its social work staff, both on an inpatient and outpatient basis. It is further recommended that social work be actively integrated into a team approach to patient care. It is clear from this study that social work plays a critical role in health care treatment. The ultimate goal at Kaiser should be to offer social work services in all areas of patient care as the treatment of the psychosocial components of physical illness must be included in a comprehensive health care program.

There is a real need for greater recognition of social workers in the Kaiser system. An integral part of a team approach to health care is the equality of the various team members. The status of social workers needs to be elevated in the medical community in order to establish a true interprofessional team approach to patient care. 
It is further recommended that in policy formulation and implementation of future health care systems (e.g., establishment of Health Maintenance Organizations) the role of social work in diagnosis, treatment, rehabilitation, and prevention be considered an essential part of comprehensive patient care. 


\section{BIBLIOGRAPHY}

Alpert, J.J. "Effective Use of Comprehensive Pediatric Care: Utilization of Health Resources." American Journal of Diseases of Children 116 (November 1968): 529-533.

Alt, Edith. "Social Work Consultation in a Prepayment Medical Care Plan." American Journal of Public Health 49 (March 1959): 350-354.

Andrepoulous, Spypos, ed. "Medical Cure and Medical Care." The Milbank Memorial Fund Quarterly 50 (October 1972) Part 2: 7-251.

Andrus, Miriam C. "Medical Social Ward Rounds - Their Contributions to Hospital Social Service." Medical Social Work 1 (October 1952): 11-21.

Balint, M. The Doctor, His Patient, and the Illness. London: Pitman Publishing Co., 1964.

Bartlett, Harriet. Analyzing_Social Work by Fields. New York: NASW, 1961.

Bartlett, Harriet. "Medical Social Work Today and Tomorrow." Medical Social Work 1 (September 1951): 1-18.

Beals, Rodney K. and Hickman, Norman. "Industrial Injuries of the Back and Extremities." The Journal of Bone and Joint Surgery 54 (December 1972): 1593-1611.

Beckhard, Richard. "Organizational Issues in the Team Delivery of Comprehensive Health Care." In The Milbank Memorial Fund Quarterly, pp. 287-316. Edited by Spypos Andrepoulous, 50 (October 1972).

Benjamin, Ruby R. and Shapiro, S. "Counseling as Preventative Medicine," Hospitals, J.A.H.A. 47 (March 1, 1973): 105-108.

Berkman, B. G. and Rehr, Helen. "The Sick-Role and the Timing of Social Work Intervention. " Social Service Review 46 (December 1972): 567-580. 
Brock, Margaret Gaughan. Social Work in the Hospital Organization. Toronto: University of Toronto Press, 1969.

Brody, Stanley J. "Common Ground: Social Work and Health Care." Health and Social Work. 1 (February 1976): 16-31.

Brown, Julia S. and Rawlinson, May. "Relinquishing the Sick Role Following Open-Heart Surgery." Journal of Health and Social Behavior 16 (March 1975): 12-27.

$\checkmark$ Cockerill, Eleanor. "The Contribution of Medical Social Work to the Team of Health Professions." Medical Social Work 1 (September 1952): 18-31.

Coleman, Jules; Lebowitz, M.L.; and Anderson, F.P. "Social Work in a Pediatric Primary Health Care Team in a Group Practice Program." Social Work in Health Care 1

(Summer 1976): 489-497.

Constitution of the World Health Orgănization, Preamble. Geneva, Switzerland: World Health Organization, 1946. Cited in Chaucey A. Alexander, "Health Care Enigmas," p. 11. Health and Social Work 1 (February 1976).

Copp, Laura A. "The Spectrum of Suffering." American Journal of Nursing 74 (March 1974): 491-495.

Davis, Michael. "What are We Heading for in Medical Care?" American Journal of Public Health 61 (April 1971): 651-653.

Deschin, Celia S. "From Concern with Problems to Emphasis on Prevention." American Journal of Orthopsychiatry 38 (January 1968): 9-17.

Donabedian, A. A Review of Some Experiences with PGP. Bureau of Public Health Economics, Research Series No. 12, Ann Arbor, Michigan: School of Public Health, 1965.

Donabedian, A. "Models for Organizing the Delivery of Personal Health Services and Criteria for Evaluating Them, "In The Milbank Memorial Fund Quarterly, pp. 103-154. Edited by Spypos Andrepoulous, 50 (October 1972). 
Donabedian, A. "Promoting Quality Through Evaluating the Process of Patient Care." Medical Care 6 (May-June 1968): 181-202.

Doremus, Bertha. "The Four Rs: Social Diagnosis in Health Care." Health and Social Work 1 (November 1976): 121 -138.

Elledge, Caroline. "The Meaning of Illness." Medical Social Work 3 (April 1953): 49-65.

Fein, R. The Doctor Storage, Washington, D.C.: The Brookings Institute, 1967.

Fink, Raymond; Goldensohn, Sidney; Shapiro, S.; and Daily, E. F. "Treatment of Patients Designated by Family Doctors as Having Emotional Problems." American Journal of Public Health 57 (September 1967): 1550-1564.

Fischer, Joel. Analyzing Research. Hawaii: University of Hawaii, School of Social Work, Research Monograph, 1975.

Forman, L. H. "The Physician and the Social Worker," American Eamily Physician 13 (January 1976): 90-93.

Freidson, Elliot. "Client Control and Medical Practice," American

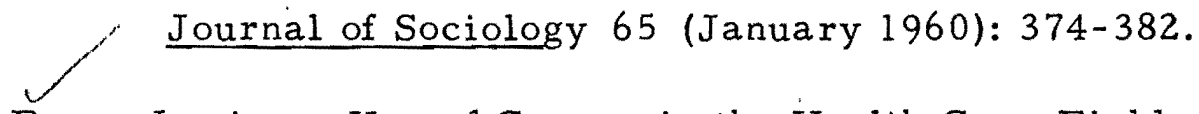

Frey, Louise. Use of Groups in the Health Care Field. New York: NASW, 1966.

Géntry, John T.; Veney, James E.; Kaluzny, Arnold D.; and Sprague, James B. "Promoting the Adoption of Social Work Services by Hospitals and Health Departments." American Journal of Public Health 63 (February 1973): 117-125.

Gerber, Abraham. The Gerber Report, New York: David McKay, 1971.

Gibson, Geof. "Explanatory Models and Strategies for Social Change in Health Care Behavior." Social Science and Medicine 6 (October 1976): 635-639.

Ginzberg, $E$ and Ostom, M. Men, Money, and Medicine. New York: Columbia University Press, 1969. 
Goldberg, Ruth. "The Social Worker and the Family Physician." Social Casework 54 (October 1973): 489-495.

Goldshine, Dora. Expanding Horizons in Medical Social Work. Chicago: University of Chicago Press, 1955.

Greenlick, M.R. "The Impact of Prepaid Group Practice on American Medical Care: A Critical Evaluation." The Annals of the American. Academy of Political and Social Science. (January 1972): 100-113.

Greenlick, M. R., ed. Conceptual Issues in the Analysis of Medical Care Utilization Behavior. Proceedings of a Conference, Rockville, Maryland: Public Health Service, HEW, 1969.

Harris, Seymour E. The Economics of American Medicine. New York: The MacMillan Co., 1964.

Hinkle, L.E. and Wolfe, H.E. "Health and Social Environment: Experimental Investigations. "In Explorations in Social Psychiatry, pp. 105-132. Edited by A.L. Leighton, New York: Basic Books, 1957.

Hinkle, L.E. and Wolfe, H. G. "The Nature of Man's Adaptation to His Total Environment and the Relation of this to Illness." AMA Archives of Internal Medicine (March 1957): 442-460.

Hobson, Caroline and Davis, W. Grayburn. "Social Work in Group Medical Practice." Group Practice 18 (June 1969): 25-30.

Hopkins, C.E., ed. Methodology of Identifying, Measuring and Evaluating Outcomes of Health Service Programs, Systems and Subsystems. Washington, D.C.: Government Printing Office, 1970.

Horvitz, D.C. "Methodological Consideration in Evaluating and Benefits." Inquiry 2 (September 1965): 96-104.

"The Humanization of Health Care: A Statement of Scope and Credo of Social Work in Health Care. "Editorial in Social Work and Health Care 1 (Fall 1975): 5.

Jaco, E. Gartley, ed. Patients, Physicians, and Illness. Glencoe, Illinois: The Free Press, 1958. 
Kane, Rosalie A. "The Interprofessional Team as a Small Group." Social Work in Health Care 1 (Fall 1975): 19-32.

Kase, Stanislav V. and Cobb, Sidney. "Health Behavior, Illness Behavior, and Sick Role Behavior." Archives of Environmental Medicine 12 (February 1966): 246-266.

Kassebaum, Gene G. and Baumann, Barbara O. "Dimensions of the Sick Role in Chronic Illness." Journal of Health and Human Behavior 6 (September 1965): 16-27.

Kennedy, Edward M. In Critical Condition: The Crisis in American Health Care. New York: Simon \& Schuster, 1972.

King, Stanley. Perceptions of Iilness and Medical Practice. New York: Russell Sage Foundation, 1962.

Klarman, H. E. The Economics of Health. New York: Columbia University Press, 1965.

Koplin, A. V.; Hutchinson, R.; and Johnson, B.K. "Influence of a Managing Physician on Multiple Hospital Admissions." American Journal of Public Health 49 (September 1959): $1174-1180$.

Korpela, Janet. "Social Work Assistance in Private Pediatric Practice." Social Casework 54 (November 1973): 537-544.

Kovner, J.W. "Measurement of Outpatient Office Visit Services." Health Services Research 4 (Summer 1969): 112-127.

Lewis, C.E. and Resnick, B.A. "Nurse Clinics and Progressive Ambulatory Care." New England Journal of Medicine 277 (December 7, 1967): 1236-1241.

Mckeown, T. Medicine in Modern Society. London: George Allen and Urwin Ltd., 1965.

McLachlan, Eileen. "Recognizing Pain." American Journal of Nursing 74 (March 1974): 496-497.

Main, Marjorie. "A Social Work Student Looks at Medical Social Work." Medical Social Work 3. (January 1954): 15-21. 
Mastrovito, Rene C. "Psychogenic Pain," American Journal of Nursing 74 (March 1974): 514-519.

Mechanic, David and Volkart, Edmund H. "Stress, Illness Behavior and the Sick Role." American Sociological Review 26 (February 1961): 51-58.

Moos, H. Coping with Physical Illness. New York: Plenum Medical Book Co., 1977.

Mullen, Edward and Dumpson, James R. and Associates, Evaluation of Social Intervention, London: Jossey-Bass, Inc., 1972.

"Notes of a Dying Professor." Pennsylvania Gazette, February 1973 , p. 30.

Olsen, Katherine M. and Olsen, Harvin. "Role Expectations and Perceptions for Social Workers in Medical Settings." Social Work 12 (July 1967): 70-78.

Parsons, Talcott. The Social System. New York: The Free Press, 1951.

Parsons, Talcott and Fox, Renee. "Illness, Therapy, and the Modern Urban American Family." Journal of Social Forces 8 (Fourth Quarter 1952): 31-44.

Perlman, Helen. "The Role Concept and Social Casework." Social Service Review 36 (March 1962): 17-31.

Petroni, Frank A. "Significant Others and Illness Behavior: A Much Neglected Sick Role Contingency. "Sociological Quarterly 10 (Winter 1969): 32-41.

Philips, Derek L. "Self-Reliance and the Inclination to Adopt the Sick Role." Social Forces 43 (May 1965): 555-563.

Polgar, Steven. "Health and Human Behavior." Current Anthropology 3 (April 1962): 159-205.

"Psychiatrists, Social Workers, and Family Doctors." The Lancet 2 (October 1975): 805-806. 
Randar, M. A.T. "Expanding Role of the Social Worker in the Health Field." American Journal of Public Health 62 (August 1972): $1102-1104$.

Rehr, Helen, ed. Medicine and Society: An Exploration in Interprofessionalism. New York: Prodist, 1974.

Reid, W and Shyne, A. Brief and Extended Casework. New York: Columbia University Press, 1969.

Rice, Elizabeth. "Concepts of Prevention as Applied to the Practice of Social Work." American Journal of Public Health 52 (February 1962): 266-274.

Richards, N. David. "Methods and Effectiveness of Health Education: The Past, Present, and Future of Social Science Involvement." Social Science and Medicine 9 (March 1975): $141-156$.

Savad, Robert J. "The Social Worker's Participation in Medical Social Ward Rounds." Medical Social Work 1 (October 1955): 22-29.

Schorr, Daniel. Don't Get Sick in America. Nashville: Aurora Publishers, Inc., 1970.

Schuval, Judith; Antonovsky, Aaron; and Davies, A. Michael. "Illness: A Mechanism for Coping with Failure." Social Science and Medicine 7 (April 1973): 259-265.

Segal, S.P. "Research on the Outcome of Social Work Therapeutic Interventions: A Review of the Literature." Journal of Health and Social Behavior 13 (March 1972): 3-17.

Segall, Alexander. "The Sick Role Concept: Understanding Illness Behavior." Journal of Health and Social Behavior 17 (June 1976): $163-170$.

Siegele, Dorothy. "The Gate Control Theory." American Journal of Nursing 74 (March 1974): 498-502.

Simon, A.J. "Social Structure of Clinics and Patient Improvement." Administrative Science Quarterly 4 (September 1959) 197206. 
Somers, Anne R. Health Care in Transition: Directions for the Future. Chicago, Illinois: Hospital Research and Educational Trust, 1971.

Somers, Anne R., ed. The Kaiser Permanente Medical Care Program: A Symposium. New York: Commonwealth Fund, 1971.

Somers, Anne R. and Somers, Herman M. Doctors, Patients, and Health Insurance Washington D.C.: Brookings Institution, 1961 .

Steinberg, Martin and Siegel, Doris. "Medical Social Service, Necessity or Luxury?" Hospitals, J.A.H.A. Reprint. March 1, 1956.

Stoeckle, John D. and Twaddle, Andrew C. "Non-Physician Health Workers: Some Problems and Prospects." Social Science and Medicine 8 (February 1974): 71-76.

Tessler, Richard and Mechanic, David. "Consumer Satisfaction with Prepaid Practice: Comparative Study." Journal of Health and Social Behavior 16 (March 1975): 95-113.

Walker, E. B.; Murawski, B.; and Thorn, G. W. "An Experimental Program in Ambulatory Medical Care." New England Journal of Medicine 271 (July 1964): 63-68.

Wenkert, W. and Terris, M. "Methods and Findings of a Local Chronic Illness Study." American Journal of Public Health 50 (September 1960): 1288-1297.

White, Kerr. "Health Care Arrangements in U.S.: A. D. 1972." In The Milbank Memorial Fund Quarterly, pp. 17-40. Edited by Spypos Andrepoulous. 50 (October 1972).

Wittman, Milton. "Social Work Manpower for the Health Services, Problems and Prospects." American Journal of Public Health 64 (April 1974): 370-375.

Zborowski, Mark. "Cultural Components in Response to Pain." Journal of Social Issues 8 (Fourth Quarter 1952): 16-30. 


\section{APPENDIX A}

INDIVIDUAL DATA SHEET

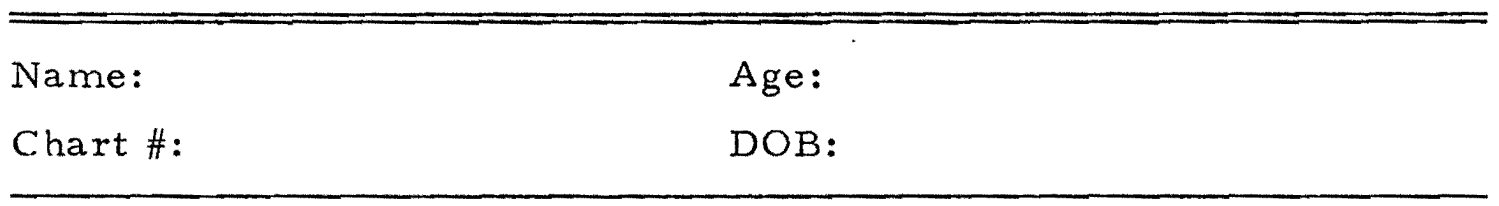

Date Office Visits $R x$ TC $R x$ ER $R x$ Hosp $R x$ DNA Other

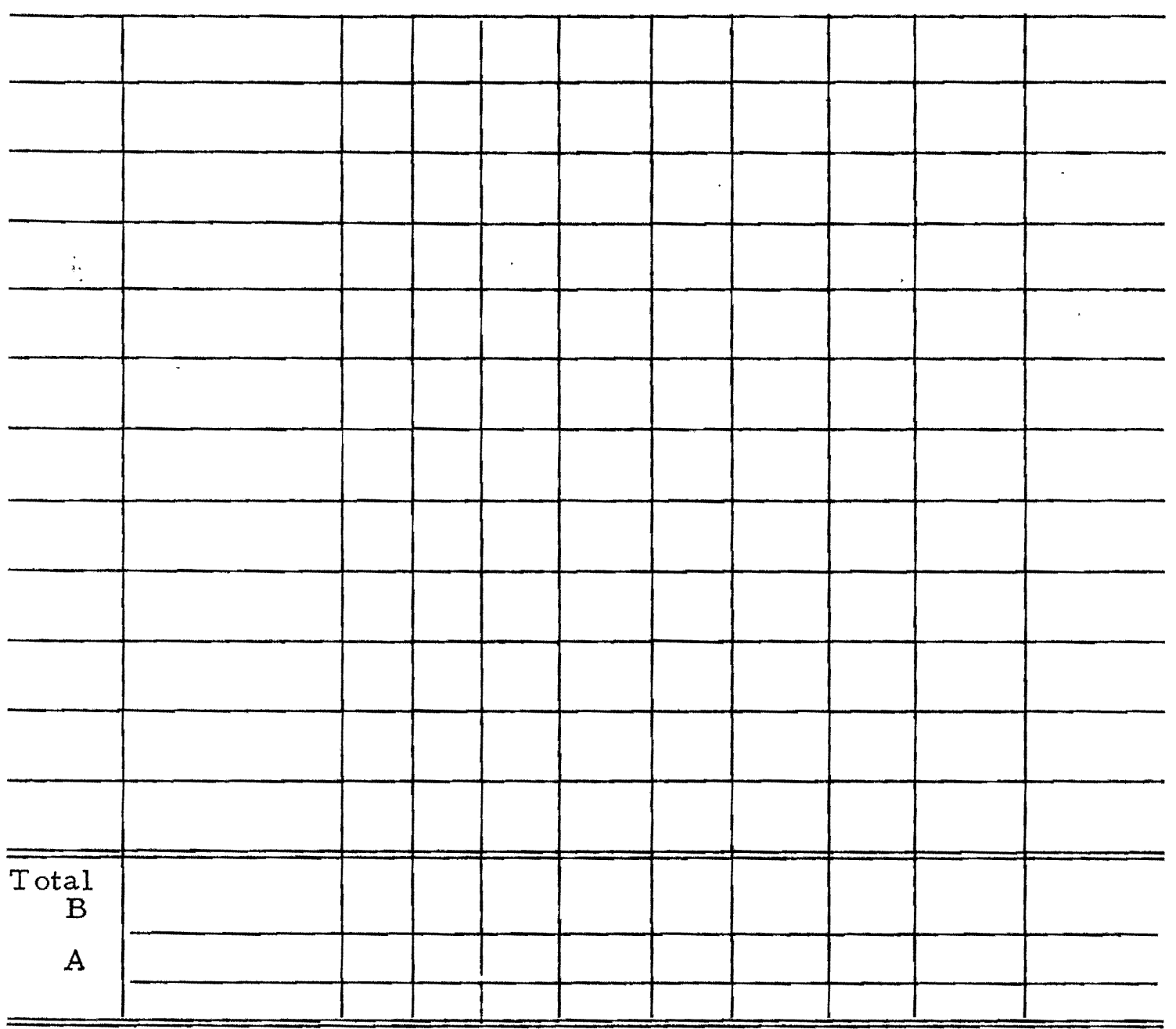




\section{APPENDIX B}

CATEGORY DATA SHEET

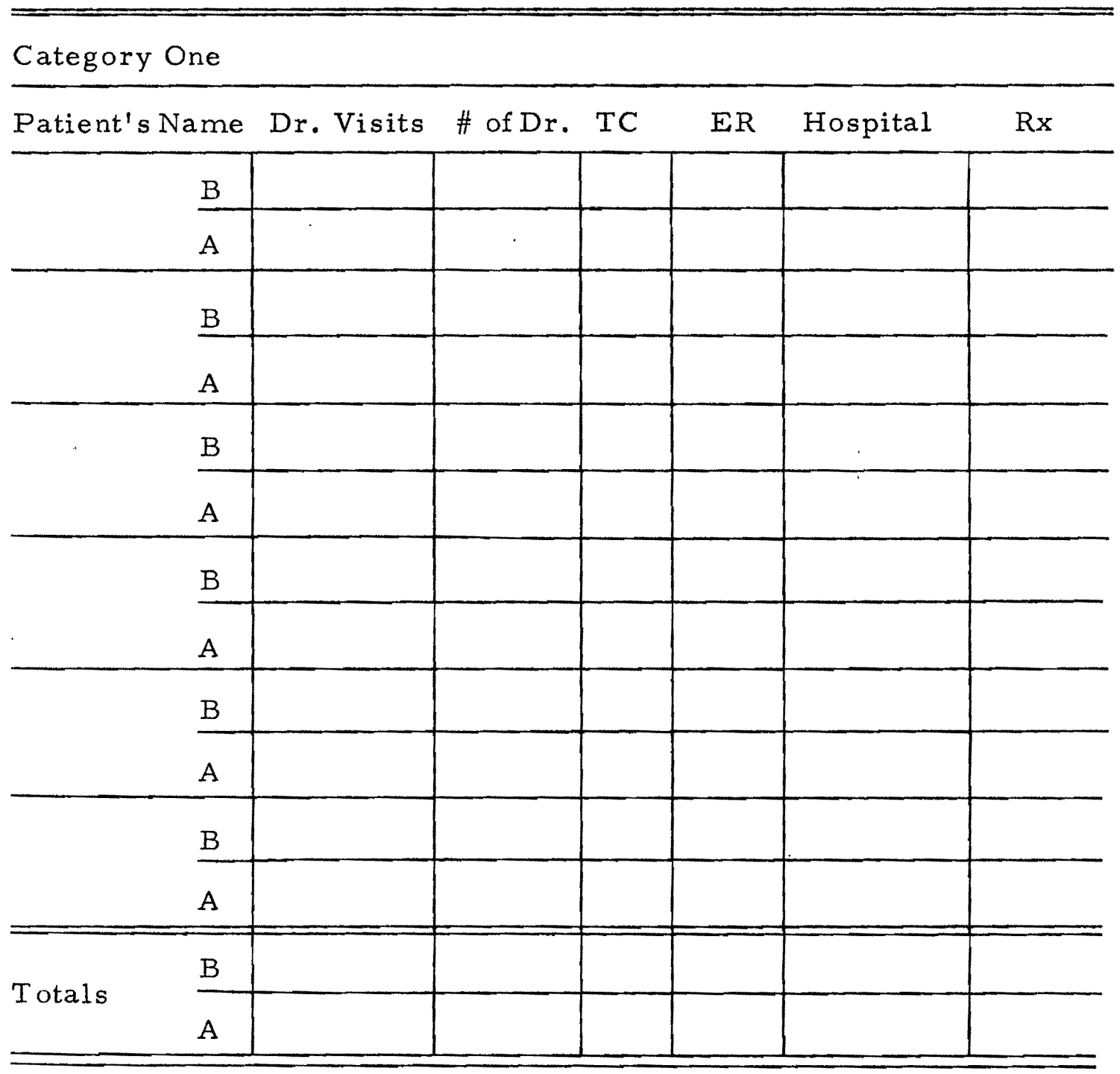

